\title{
Corrosion Assessment of ASME Qualified Welding Procedures for Grade 2101 Lean Duplex Stainless Steel
}

DOI:

$10.5006 / 3257$

Document Version

Accepted author manuscript

Link to publication record in Manchester Research Explorer

\section{Citation for published version (APA):}

Guilherme, L. H., Reccagni, P., Benedetti, A., Fugivara, C. S., \& Engelberg, D. (2019). Corrosion Assessment of ASME Qualified Welding Procedures for Grade 2101 Lean Duplex Stainless Steel. Corrosion. https://doi.org/10.5006/3257

\section{Published in:}

Corrosion

\section{Citing this paper}

Please note that where the full-text provided on Manchester Research Explorer is the Author Accepted Manuscript or Proof version this may differ from the final Published version. If citing, it is advised that you check and use the publisher's definitive version.

\section{General rights}

Copyright and moral rights for the publications made accessible in the Research Explorer are retained by the authors and/or other copyright owners and it is a condition of accessing publications that users recognise and abide by the legal requirements associated with these rights.

\section{Takedown policy}

If you believe that this document breaches copyright please refer to the University of Manchester's Takedown Procedures [http://man.ac.uk/04Y6Bo] or contact uml.scholarlycommunications@manchester.ac.uk providing relevant details, so we can investigate your claim.

\section{OPEN ACCESS}




\title{
Corrosion Assessment of ASME Qualified Welding Procedures for Grade 2101 Lean Duplex Stainless Steel
}

\author{
L.H. Guilherme ${ }^{a, b}$, P. Reccagni ${ }^{c}$, A.V. Benedetti ${ }^{b}$, C.S. Fugivara ${ }^{b}$, D.L. Engelberg ${ }^{c, d}$ \\ ${ }^{a}$ Soudap Engineering Company, 14803-655, Araraquara, Brazil \\ ${ }^{\mathrm{b}}$ São Paulo State University - UNESP, Chemistry Institute, 14800-900, Araraquara, Brazil \\ ${ }^{c}$ Corrosion and Protection Centre, School of Materials, The University of Manchester, M13 9PL, \\ Manchester, United Kingdom \\ ${ }^{d}$ Materials Performance Centre, School of Materials, The University of Manchester, United \\ Kingdom
}

\begin{abstract}
ASME qualified welding procedures do not guarantee suitable corrosion and passivation properties for lean duplex stainless steel welds. An evaluation of two ASME qualified welding procedures to optimize the corrosion performance of TIG welded grade 2101 duplex stainless steel using ER2209 weld consumable was conducted. The evolution of the microstructure was examined by optical and electron microscopy, ferrite-scope measurements, and Scanning Kelvin Probe Force Microscopy (SKPFM). An electrochemical mini-cell was then used to characterize the electrochemical behaviour of different weld regions using the techniques such as the double loop electrochemical potentio-kinetic reactivation test, standard potentiodynamic polarization tests, and cyclic potentio-dynamic polarization. The fusion line was the most critical zone for localized corrosion for both welding procedures, due to the formation of $\mathrm{Cr}$ and Mo depleted zones, resulting in the highest degree of sensitization. The best performance was attributed to the weld face, due to the presence of higher $\mathrm{Cr}$ and $\mathrm{Mo}$ contents, highlighting the pitting corrosion resistance. A heat input range of $1.6-1.9 \mathrm{~kJ} / \mathrm{mm}$ and low current density (WPS1) indicated better corrosion performance of all weld regions. The electrochemical corrosion response was in all cases related to microstructural characteristics of the weld regions. The influence of weld parameters on microstructure development and corrosion performance is discussed.
\end{abstract}

Key-words: Grade 2101 duplex stainless steel, TIG welding, SKPFM, electrochemical testing, DL-EPR testing. 


\section{Introduction}

Duplex stainless steels are of great technological importance due to the balanced combination of beneficial mechanical properties with excellent corrosion and stress corrosion cracking resistance, which is related to their dual-phase microstructure ${ }^{1,2}$. A number of different duplex stainless steel grades exist, typically classified with respect to their Pitting Resistance Equivalent Number (PREN), which provides an estimation of their corrosion resistance ${ }^{3}$. Lean duplex stainless steel (e.g. grades 2101, 2202) was introduced as an economical alternative to the grade 2205 standard duplex composition. These grades contain lower Ni and Mo contents, which is compensated by an increase in $\mathrm{Mn}$ and $\mathrm{N}$ content to stabilize the austenite phase in the duplex microstructures. Despite several studies on grade 2101 stainless steel, research regarding the influence of welding procedure on the microstructure of weld microstructures and their performance in corrosive environment are still limited ${ }^{3-11}$.

Aseptic storage tanks are generally built by using grade $304 \mathrm{~L}$ austenitic stainless steel, but the potential application of the lean grade 2101 is currently explored. The latter has been reported to possess better passivation properties ${ }^{12}$, and the thickness of plate can be reduced due to its higher tensile strength. For application in construction, the welding procedure specifications (WPS) are qualified according to the ASME code section $I X^{13}$, which defines welding settings and associated qualification tests. Despite the use a qualified welding procedure, it is not guaranteed that these settings are optimised to obtain suitable passivation properties of the exposed surface of the welded joint, because the qualification tests are centred on optimising mechanical properties. In addition, the weld inspection focuses on controlling the heat input (maximum of $2.5 \mathrm{~kJ} / \mathrm{mm}$ ) and interpass temperature (maximum of $150{ }^{\circ} \mathrm{C}$ ), which can be insufficient to avoid metallurgical discontinuities, such as $\mathrm{Cr}$ - or Mo-depleted zones ${ }^{14,15}$.

This work aims to optimize the corrosion resistance of TIG welded grade 2101 duplex stainless steel. The welding parameters applied for welding vertical sections of an aseptic tank shell were physically simulated on laboratory scale. Two ASME qualified welding procedures used at the construction site were simulated, with weld microstructures and their corrosion performance characterised by microscopy techniques and electrochemical corrosion tests.

\section{Materials and methods}

A lean duplex stainless steel grade 2101 (UNS S32101) sheet and AWS ER2209 (AWS A5.9) weld consumable with the chemical compositions given in Table 1 were used in this study. The 
sheet was received as $6 \mathrm{~mm}$ thick coil supplied by Outokumpu Stainless $A B$, and the weld metal in the form of ER2209 weld rod with $3.2 \mathrm{~mm}$ diameter.

Two ASME IX qualified welding procedure specification (WPS) were compared with respect to corrosion resistance requirements. Single $\mathrm{V}$ groove welded joints were prepared, using a oneside welding technique. A flux of argon ( $20 \mathrm{~L} / \mathrm{min}$ in the purge) was used to support the root and filler passes (backing). Manual TIG welding was performed using an EWM Tetrix 351 Confort FW weld machine in the vertical position, with all welding parameters summarised in Table 2 (a) and (b). The heat input was calculated using ASME IX by dividing the average power (current $x$ voltage) by the travel speed $(\mathrm{mm} / \mathrm{s})$. A TIG welding procedure was applied to deposit four weld beads. Each WPS was carried out with specific parameters (Table 2) and the layer geometries shown in Figure 1.

WPS 1 used lower current and travel speed that generated higher heat input, and two cover weld passes were applied with individual widths of $6.0 \mathrm{~mm}$. On the other hand, the WPS 2 was set up with a higher current and travel speed, which resulted in lower heat input. It is important to point out that WPS 2 had only one cover weld pass with a width of $12 \mathrm{~mm}$. Both WPS 1 and 2 used a large filler pass with a width of $8-9 \mathrm{~mm}$, but the change in the heat input was greatest at WPS 1, as can be seen in the second weld pass of Table 2(a).

Metallographic characterization was carried out of all weld regions. All specimens were mounted in polyester cold cure resin, ground to 4000 grit, and polished to colloidal silica solution $(0.04 \mu \mathrm{m})$ finish. Metallographic etching was carried out in aqueous $10 \%$ (wt.) oxalic acid solution, by applying a current density of $1 \mathrm{~A} \mathrm{~cm}^{-2}$ for $20 \mathrm{~s}$. This procedure is known to selectively outline microstructure heterogeneities, such as interphases and grain boundaries, and in particular areas with higher chromium contents ${ }^{16-18}$. The latter etching procedure is applied to reveal $\mathrm{Cr}$-enriched regions at ferrite/austenite interfaces, grain boundaries, as well as intragranular precipitates, such as chromium-nitrides. The resulting microstructures were observed with an Olympus CX31 optical microscope (OM) and JEOL JSM-7500F scanning electron microscope (SEM), equipped with a PC-SEM v.2.1.0.3 analyser. Additionally, ferrite content measurements were performed with a ferrite-scope (Fisher FMP30) to estimate the volume fraction of ferrite in the different weld regions, shown in Figure 1. 
Previous studies demonstrated that the heat-affected zone (HAZ) is the region most susceptible to localized corrosion in welded joints due to large local variations in the chemical compositions ${ }^{3,11,19-25}$. Therefore, the local chemical composition variations of the austenite and ferrite phase were investigated by EDX (Energy Dispersive X-ray) analysis. EDX data were acquired using an $80 \mathrm{~mm}^{2} \mathrm{X}$-Max detector, collecting $10^{6}$ counts for each point, and the EDX spectra were quantified using ZAF correction of the Aztec software. For each phase (austenite and ferrite) five spectra were acquired, and this procedure was applied for the base metal, weld face, weld root, HAZ of weld root, and HAZ of weld face.

SKPFM measurements were performed on the same weld regions over an area of $80 \mu \mathrm{m} \times 80$ $\mu \mathrm{m}$. The measurements were performed with a Dimension D3100 atomic force microscope (AFM) using platinum-coated tips (OSCM-PT) with $25 \mathrm{~nm}$ tip radius. Volta-Potential $(\Delta \Psi)$ measurements were obtained at room temperature, with an interleave lift height of $50 \mathrm{~nm}$ at $0.2 \mathrm{kHz}$ scan frequency. The Nanoscope Analysis V1.5 acquisition programme was used to investigate the Volta-Potential maps.

For corrosion testing, a customized electrochemical mini-cell with diameter of $1.5 \mathrm{~mm}$ was used $^{26}$, with a platinum counter electrode and a $\mathrm{Ag}|\mathrm{AgCl}| \mathrm{KCL}\left(3 \mathrm{~mol} \mathrm{~L}^{-1}\right)$ reference electrode. The positions for analysis carried out on the weld regions are summarised in Figure 1, classified as base metal (BM), weld face (WF), weld root (WR), and fusion line (FL). Five measurements of each test type were made in each region, with polarization scans started typically 5 min after making contact with the electrolyte, and all measurements were performed at ambient temperature $\left(25^{\circ} \mathrm{C}\right)$. A Palmsens v. 3 potentiostat was operated using commercial PSTrace v. 3.4 software. A number of different electrochemical measurements were carried out with the micro-cell, including double loop electrochemical potentio-kinetic reactivation (DL-EPR) test, standard potentio-dynamic polarization (PDP) tests, and cyclic potentio-dynamic polarization (CPP) assessments.

The DL-EPR test was applied to measure the degree of sensitization (DOS) of the weld microstructure regions by using two different electrolytes: (i) standard DL-EPR solution of 0.5 $\mathrm{mol} \mathrm{L}^{-1} \mathrm{H}_{2} \mathrm{SO}_{4}+0.01 \mathrm{~mol} \mathrm{~L}^{-1} \mathrm{KSCN}$ and (ii) a more aggressive $2.0 \mathrm{~mol} \mathrm{~L}^{-1} \mathrm{H}_{2} \mathrm{SO}_{4}+0.5 \mathrm{~mol} \mathrm{~L}^{-1} \mathrm{HCl}$ solution. The first test environment (i) was used for determining the DOS of stainless steels by evaluating the charge ratio of the cathodic re-activation vs. anodic activation loop $\left(\left(Q_{r} / Q_{a}\right) \times\right.$ 100 ), in combination with microstructure observation by SEM after the electrochemical measurements. The second test environment (ii) is used to characterise activation loop differences of duplex stainless steel, by comparing the integrated charge density of the 
activation loop $\left(Q_{a}\right)$. For both assessments, the electrochemical potential was scanned first in the anodic direction, from $-500 \mathrm{mV}_{\mathrm{Ag} / \mathrm{AgCl}}$ to $+300 \mathrm{mV}_{\mathrm{Ag} / \mathrm{AgCl}}$, where the polarization scan was reversed, and scanned back to $-500 \mathrm{mV}_{\mathrm{Ag} / \mathrm{AgCl}}$. A sweep rate of $1.67 \mathrm{mV} \mathrm{s}^{-1}$ was used for both tests.

Standard PDP tests in $2.0 \mathrm{~mol} \mathrm{~L}^{-1} \mathrm{H}_{2} \mathrm{SO}_{4}+0.5 \mathrm{~mol} \mathrm{~L}^{-1} \mathrm{HCl}$ aqueous solution were also performed over a wide range of electrochemical potentials to identify the most suitable interval to observe the austenite and ferrite activation peaks ${ }^{27}$. Polarization scans were then repeated over a smaller potential range, focusing on the activation peaks, with scans carried out from $50 \mathrm{mV}$ vs. OCP to $-80 \mathrm{mV}_{\mathrm{Ag} / \mathrm{AgCl}}$ using a scan rate of $0.1 \mathrm{mV} \mathrm{s}^{-1}$. A Gaussian deconvolution of the activation peaks was performed to understand the contributions of ferrite and austenite on the anodic current density and the potentials in the active-to-passive transitions region for each microstructure region of both welding procedures.

CPP tests were performed in $3.5 \% \mathrm{NaCl}$ solution to evaluate the pitting corrosion resistance. After stabilization of the OCP (5 min), an anodic polarization scan was performed at a sweep rate of $1.67 \mathrm{mV} \mathrm{s}^{-1}$. The anodic scan was reversed at a current density of $1 \mathrm{~mA} \mathrm{~cm}$, with the sample then being scanned in the cathodic direction to a potential of $-200 \mathrm{mV} v$ s. OCP.

\section{Results}

Metallographic images of the welded microstructure regions shown in Figure 1 are summarised in Figure 2. The BM has a austenite:ferrite ratio of $56: 44$, showing a typical banded microstructure without any evidence of local chromium enrichment or depletion. The weld face shows the typical lath-type Widmannstaetten austenite, formed due to shear assisted diffusional transformation. The fusion zone (FZ) microstructure consist of austenite grains in the form of Widmanstätten laths and secondary austenite $\left(\gamma_{2}\right)$ within a matrix of ferrite, typically observed in lean duplex stainless steel weldments ${ }^{3,11,28}$. The fusion line is the boundary among the heat affected zone (HAZ) and the $F Z$, and this region showed the highest proportion of ferrite. Quench-in chromium nitride precipitates were also present, predominantly within ferrite grains. Figure 2 presents the microstructure of the welded joints regions (BM, HAZ, FZ) and the nitride colonies within the ferrite grains mainly in the HAZ and weld root. 
The ferrite measurements via ferrite-scope as a function of weld region and welding procedures are summarised in Figure 3 . The $\mathrm{FN}$ was initially around $42.3 \%$ for the $\mathrm{BM}$, and increased for all weld regions. WPS 1 had, compare to WPS2, a reduced ferrite count in the weld face $(44 \%)$ and the weld root $(49 \%)$, but a similar value $(53 \%)$ in the fusion line. The latter ferrite number (FN) was possibly related to the far higher heat input of the second weld pass of $2.49 \mathrm{~kJ} / \mathrm{mm}$ (see Table 1). WPS 2 had the highest FN in all four investigated regions.

The chemical composition of austenite and ferrite within the welded regions were measured, and the compositional differences caused by local element segregations are similar to observations made by Westin et al. ${ }^{3}$. The elemental compositions of the different weld regions and differences in austenite and ferrite are summarised in Table 3, with the data then interpreted using PREN calculations in Figure $4^{29}$. The higher composition of the ER2209 weld consumable is clearly represented in the weld face. Both welding procedures show, in general, similar PREN values for all assessed regions, with the HAZ indicating the most $\mathrm{Cr}$ depleted regions. If compared to the base metal composition, the HAZ ferrite is depleted of both $\mathrm{Cr}$ and Mo, with the PREN indicating the lowest values for both WPS. In general, the performance of WPS 1 regarding the chemical composition and associated PREN values are slightly higher than the values of WPS 2. Figure 4 demonstrates the better performance of WPS 1, which shows the PREN values of base metal, weld root and HAZ of face and root.

\section{SKPFM Assessment}

SKPFM measured Volta potentials were used to investigate the potential variations between the weld regions of both welding procedures. Each phase (austenite and ferrite) was characterised using a line-scan of $10 \mu \mathrm{m}$ length. Figure 5 presents the typical Volta potential maps and schematized line-scan in the base metal (Fig. 5a), weld face (Fig. 5b) and in the fusion line (Fig. 5c) of the WPS 2. It is important to point out that in Figure 5c Cr-nitride containing zones are present in the fusion line. Volta potential maps for all regions showed small variations within each phase, but no obvious potential hot-spots (individual sites with high local $\Delta \Psi)$. It is noteworthy that differences in Volta potential measured indicate a driving force for galvanic interaction, since regions with large potential gradients $(\Delta \Psi)$ indicate susceptibility for localized corrosion ${ }^{30}$. These results indicate the existence of a driving force for 
galvanic interaction among austenite and ferrite, which cause the electrochemical activity at interphase boundaries, with the dissolution occuring towards the ferrite phase $\mathrm{e}^{30-32}$.

The Volta potential variation among austenite and ferrite was measured for the all regions shown in Figure 1 for both welding procedures, with data summarized in Figure 6. For all regions, the austenite presented cathodic character vs the ferrite, and the average austeniteferrite Volta potential difference in the base metal was $+36 \mathrm{mV}$. A reduced potential variation among the phases was observed in the weld face and weld root for the WPS 1, while WPS 2 presented potential variation similar to the base metal, with a smooth reduction of Volta potentials towards the weld face.

Besides the regions shown in Figure 1, the Volta potential measurements also evaluated the $\mathrm{Cr}$-nitride containing zones shown in Figure $1 \mathrm{~d}$ and $5 \mathrm{c}$. These regions presented a large austenite-ferrite Volta potential difference, with variation of up to $45 \mathrm{mV}$. Then supports the presence of an increased local galvanic activity in regions where $\mathrm{Cr}$ nitrides are present. The differences in Volta potential for both welding procedures are given in Figure 6. A clear trend is apparent, with WPS2 showing a relatively constant Volta potential difference between ferrite and austenite. The weld face and root of WPS1 show far lower differences of only 15-20 mV compared to all other measured values, inline with lower ferrite counts of both regions (Figure 3). This would certainly mean that ferrite stabilising elements are partly re-distributed into the austenite, which in turn would also affect the corrosion resistance and associated Volta potential differences. ${ }^{29}$

\section{Degree of Sensitisation (DOS)}

Figure 7 presents typical DL-EPR curves of the fusion line of WPS1 and WPS2 obtained in $(a, b)$ $0.5 \mathrm{~mol} \mathrm{~L}^{-1} \mathrm{H}_{2} \mathrm{SO}_{4}+0.01 \mathrm{~mol} \mathrm{~L}^{-1} \mathrm{KSCN}$ aqueous solution and $(\mathrm{c}, \mathrm{d})$ obtained in in $2.0 \mathrm{~mol} \mathrm{~L}^{-1}$ $\mathrm{H}_{2} \mathrm{SO}_{4}+0.5 \mathrm{~mol} \mathrm{~L}^{-1} \mathrm{HCl}$ environment. DL-EPR DOS values and corresponding activation charge densities (Qa) of all weld regions of both welding procedures are compared in Table 4. Posttest SEM investigation indicated that the reactivation peaks of the DL-EPR test can be attributed to the preferential corrosion attack of $\mathrm{Cr}$-depleted regions around $\mathrm{Cr}$-carbides and $\mathrm{Cr}$-nitrides. The presence of other tertiary phases, such as $\sigma_{-}, \alpha^{\prime}-, \mathrm{G}-$ and Chi-phase can also promote increased DL-EPR values, but these were not found here in our lean duplex microstructures ${ }^{16,28,33,34}$. In general, WPS 1 resulted in lower DOS values than WPS 2 when tested in $0.5 \mathrm{~mol} \mathrm{~L}^{-1} \mathrm{H}_{2} \mathrm{SO}_{4}+0.01 \mathrm{~mol} \mathrm{~L}^{-1} \mathrm{KSCN}$ solution. WPS 2 showed significant sensitisation 
of the fusion line and the weld root regions. Small DOS variation of the different regions (e.g face vs root in WPS1) should be treated with caution, since small differences can be a function of the size of the chromium-depleted zones present within the tested surface area of the minicell used ${ }^{26,33,34}$. A distinct difference between root, face and fusion line is observed in WPS2.

Tests in $\mathrm{H}_{2} \mathrm{SO}_{4}+\mathrm{HCl}$ solution were also performed to comprehend the electrochemical behaviour of all weld regions in a more aggressive electrolyte. In this environment, reactivation peaks were not observed, which is possibly related to the formation of an intact passive film at the surface after the anodic scan, combined with the lack of a de-passivating agent (KSCN) in the solution. The corrosion performance of the different weld regions can be analysed based on the activation charge $\left(Q_{a}\right)$, which has been reported to be primarily related to ferrite dissolution ${ }^{27,35}$.in this electrolyte, WPS 1 also showed lower $Q_{a}$ values than WPS 2 for all regions, shown in Figure 7 (c,d) and Table 4.

Figure 8 show SEM images of the weld region after DL-EPR testing in $0.5 \mathrm{~mol} \mathrm{~L}^{-1} \mathrm{H}_{2} \mathrm{SO}_{4}+0.01 \mathrm{~mol}$ $\mathrm{L}^{-1} \mathrm{KSCN}$ solution. The DL-EPR test carried out here on lean duplex stainless steel induces corrosion attack on the ferritic phase and along interphase boundaries. The images shown relate the DOS value with surface attack observed due the corrosion. The surfaces of all regions after DL-EPR testing are consistent with microstructural observations reported in Figure 2. Once a significant deterioration of the corrosion resistance of the ferrite phase was observed, higher DOS values were obtained from attack of the grain interior and along interphase boundaries. Figure 2 presents $\mathrm{Cr}$-nitride containing zones observed in some weld regions, which is also in line with surface deterioration reported in Figure 8. It is worth mentioning that tertiary phase formation is mainly related to phase transformation taking place inside the ferrite. The interphase boundaries are also heavily corroded, with the austenitic phase showing no significant dissolution. The presence of $\mathrm{Cr}$-nitrides in conjunction with $\mathrm{Cr}$-depleted zones in the ferritic matrix, and the preferred nitrogen and nickel partitioning in the austenite renders enhanced passivation behaviour to the austenite, resulting in more selective dissolution of the ferrite ${ }^{18,31,32,34-36}$. 


\section{Ferrite/Austenite - Electrochemical Activity}

The environment containing $2 \mathrm{~mol} \mathrm{~L}^{-1} \mathrm{H}_{2} \mathrm{SO}_{4}+0.5 \mathrm{~mol} \mathrm{~L}^{-1} \mathrm{HCl}$ in Figure 9 enhanced the anodic current density in the active-to-passive transition region, and it is important to point out that two distinguishable peaks were observed in this region, consistent with those reported by other authors ${ }^{29,35}$. According to the literature ${ }^{27}$, preferential dissolution of ferrite phase occurred at lower peak potential $(\approx-270 \mathrm{mV}$ to the base metal), while the austenite phase corroded at a fast rate at higher peak potential $(\approx-220 \mathrm{mV}$ to the base metal). This electrochemical behaviour provides a specific analysis based on the critical potential for dissolution of ferrite and austenite $\left(E_{\alpha \max }\right.$ and $\left.E_{\gamma \max }\right)$ and their corresponding anodic current density $\left(I_{\alpha \max }\right.$ and $\left.I_{\gamma \max }\right)$. Figure 9 also gives potential ranges to show the potentials peaks for both WPS 1 (inset in a) and WPS 2 (inset in b).

A Gaussian deconvolution was applied to the peak profiles in order to assess the austenite and ferrite contribution in the active-to-passive transition region observed ${ }^{27}$, as demonstrated in Figure 10. It is noteworthy that the curves of the fusion line did not permit to be deconvoluted into active-to-passive transition region, probably due to the weld dilution processes between weld metal and base metal. At potential range between $E_{\alpha \max }$ and $E_{\gamma \max }$ the preferential dissolution of individual phases and its reversion can be observed, highlighting that below $\mathrm{E}_{\alpha \mathrm{max}}$ the dissolution rate of $\gamma$ phase is lower than that of $\alpha$ phase and, on the other hand, above $E_{\text {pmax }}$ both phases are in passive state ${ }^{27}$. Based on $E_{\max }$ and $I_{\max }$ of both phases, the performance of the weld face in WPS 1 is slightly better than the weld root in WPS 1 and the weld face of WPS 2. The weld root of WPS 2 presented higher $I_{\alpha \max }$ and lower $E_{\alpha \max }$, which indicate that this region will be severely attacked.

\section{Pitting Corrosion Resistance}

Cyclic potentiodynamic polarization curves in $3.5 \% \mathrm{NaCl}$ solution are presented for the weld regions in Figure 11. All polarization curves showed a passive behaviour of the weld regions, with no evidence of an re-activation current peak when the potential was reversed ${ }^{37}$. The base metal had a large current spike, indicative of crevice corrosion, possibly caused by the minielectrochemical cell used. 
The PREN values of all different regions are compare to the breakdown potentials ( $\left.E_{\text {pit }}\right)$ of both welding procedures and the different regions in Table 5. WPS 1 showed a similar performance of the weld face and root. The $E_{\text {pit }}$ were registered for all weld regions of WPS 2, probably due to the presence of $\mathrm{Cr}$-nitrides and $\mathrm{Cr}$-depletion in these regions, which are the preferential sites to pit nucleation ${ }^{11,35,38-40}$. The fusion line of both welding procedures had lower $E_{\text {pit }}$ and a positive hysteresis. This observation supports the presence of a critical microstructure zone, in the form of the fusion line, for the corrosion performance of lean Duplex welded joints in chloride solution. The fusion line had an $E_{\text {pit }}$ value range of $+250-300 \mathrm{mV}$ and the PREN range of the ferrite phase was 20.10-20.20. The weld root of the WPS 2 obtained an $E_{\text {pit }}$ of $+555 \mathrm{mV}$ with a similar PREN of the ferrite. One of the factors that influenced these results were the difference among PREN values of austenite phase. The weld root region had a better performance due to the better PREN of austenite phase, since the PREN of ferrite were similar (between fusion lines and root). Therefore, although the weak phase is the ferrite it defines the corrosion performance for dual phase stainless stee ${ }^{41}$, it is important to consider the PREN of austenite phase in the corrosion performance analysis.

The electrochemical parameters obtained from CPP testing are summarized in Figure 12, which presents the corrosion potential $\left(E_{\text {corr }}\right)$, pitting potential $\left(E_{\text {pit }}\right)$, protection (repassivation) potential $\left(E_{r p}\right)$, and passive region $\left(E_{r p}-E_{c o r r}\right)$. In addition, it can be asserted that the fusion line has not a constant electrochemical behaviour along its length. Figure 13 presents a comparative study that evaluated two different points at the same fusion line: (a) fusion line near weld face, and (b) fusion line near weld root. It is evident the best performance of the fusion line near the face, according to the CPP curves. This is evidence that the thermal history of the multi-pass welded joint can cause the decrease of corrosion performance due to changes in the microstructure and their ability to passive film formation in this region. Also, this point of view is useful to the industrial facilities manufacturer to choose the weld surface that it will be exposed to the corrosive environment (e.g. tube sheet weld of heat exchanger) to avoid the surface degradation during equipment operation ${ }^{23,26,42,43}$. 


\section{Discussion}

Comparing the microstructural observations of the present work with those of Westin ${ }^{4}$, the influence of peak temperature and cooling rate on the weld microstructure, austenite / ferrite ratio, and $\mathrm{Cr}$-depleted and $\mathrm{Cr}$-nitride containing regions has been observed. It is considered that the arc welding process has moderate cooling rates, and the microstructure of the weld joint forms a fraction of lamellar Widmanstätten austenite. Secondary austenite is also observed when supersaturated ferrite, containing chromium nitride precipitates, is reheated by subsequent multipass welding ${ }^{34,44}$. The most frequently reported chromium nitride $\mathrm{e}^{4,28,34,45}$, and its formation is related to the rapid cooling and high ferrite contents. So, convergences between the microstructural characterization and the welding procedures were observed. The WPS 1 used a higher heat input and the travel speed was significantly slower resulting in a smaller cooling rate, which resulted in higher austenite level and reduction of chromium nitrides precipitation. The WPS 2 used a high peak temperature (related to current density) and rapid cooling rate (related to high travel speed), prejudicing the driving force for austenite growth. This welding setup resulted in higher ferrite content to the HAZ and weld root due the multipass weld condition, including high $\mathrm{Cr}_{2} \mathrm{~N}$ levels for these regions. Another difference among the welding procedures is associated to the layers and passes width, once large passes can prejudice the partition of alloy elements during welding solidification and, consequently, influence the corrosion performance ${ }^{3}$.

The fusion line of both welding procedures resulted in a degraded structure due to the multipass thermal cycle of welding. Brandi et al. ${ }^{34}$ detailed the potential problems related to the high temperature HAZ (HTHAZ), where the fusion line is located. These conditions were evident in the chemical composition variation of austenite and ferrite phases (table 3 ) and by SKPFM measurements. The difference in the chemical composition between the austenite and ferrite was reduced due to the initial solidification of ferrite and fast cooling that provided diffusion of heavy elements in short distance ${ }^{34}$. In addition, this condition caused reduction of chromium content in the ferrite phase and became more susceptible to localized corrosion attack $^{44-46}$, highlighting the decrease of the ferrite PREN in fusion line regions. The chemical composition variations of phases had direct influence in the quality of the passive film formation in each phase. The Volta potential difference demonstrated that the austenite has cathodic behaviour relative to the ferrite, and higher values were observed in the fusion line, This clearly demonstrated the galvanic interaction between ferrite and austenite. 
The DL-EPR tests performed in $0.5 \mathrm{~mol} \mathrm{~L}^{-1} \mathrm{H}_{2} \mathrm{SO}_{4}+0.1 \mathrm{~mol} \mathrm{~L}^{-1} \mathrm{KSCN}$ were suitable to assess the DOS. Once the fusion zone for a single pass has balance of approximately equal amounts of ferrite and austenite for optimum corrosion resistance and mechanical properties ${ }^{4,14,34}$, the DOS for this microregion indicated homogeneous microstructure without depleted zones, as can be seen for the weld face of WPS 1. The WPS 1 obtained a better performance than WPS 2 for the weld face and root regions due to the welding parameter setting. This statement is not applicable to the fusion line, where both welding procedures obtained a non-satisfactory performance. It is noteworthy that there was a consistent relationship between DOS values and ferrite content. When ferrite content is increased the probability to $\mathrm{Cr}_{2} \mathrm{~N}$ precipitation is also higher, and the DOS variation occurred as a function of the number of chromium-depleted zones presents on the scanned surface area. Figure 14 presents, for both welding procedures, the correlation between DOS and ferrite content, noticing the logarithmic trendline that obtained R-squared values greater than 0.91 , which is a good fit of the line to the data. When the ferrite content was superior to $50 \%$, an expressive increase in DOS was observed.

The SEM images in Fig. 8, obtained after DL-EPR testing in $0.5 \mathrm{~mol} \mathrm{~L}^{-1} \mathrm{H}_{2} \mathrm{SO}_{4}+0.01 \mathrm{~mol} \mathrm{~L}^{-1}$ $\mathrm{KSCN}$, demonstrate that the ferrite phase and the interphase boundaries were the preferential sites for localized corrosion, and the degradation increased proportionally to the DOS. The passive film obtained with WPS 1 had better quality than that of WPS 2, according to the Volta potential measurements (Fig. 5) and activation charges (Fig. 9) for all regions. In addition, the Gaussian deconvolution of the active-to-passive transition regions was useful to demonstrate the consequences of the microstructural changes on the global electrochemical behaviour of each weld region. The determine $E_{\max }$ and $I_{\max }$ parameters of each phase demonstrated that the weld face presents a nobler electrochemical behaviour and reduced anodic peak compared to the weld root. In the fusion line, with high content of ferrite, the activation peak takes up a larger area of the active-to-passive region of the potentiodynamic curve and, probably, a larger difference between the potentials of the phases is noted, inhibiting the deconvolution in two anodic peaks. Thus, the preferential dissolution of ferrite occurred, as shown in Figure 8e.

The cyclic polarization study supported the previous results, where WPS 1 presented a better electrochemical behaviour in weld face and root, and similar performance of the fusion line compared to WPS 2. A lower corrosion resistance was observed in the fusion line, with sites of pit nucleation probably related to chromium nitride particles, as reported by Tan et al. ${ }^{47}$. The higher susceptibility of the fusion line to preferential corrosion is related to microstructural 
evolution during welding. The volume fraction of the ferrite is increased in the fusion line and the $\mathrm{Cr}$ and Mo content are diluted, resulting in decreased concentration of these alloying elements in ferrite phase. $\mathrm{Cr}_{2} \mathrm{~N}$ also typically precipitates in the ferrite phase due to the lower solubility of nitrogen in this phase ${ }^{15,28,34,39,47}$. Examination of Table 3 and Figure 13 confirms the relation between microstructural features, thermal history of welds and electrochemical behaviour.

At construction sites using lean grade 2101 duplex stainless steel, welding quality control only based on heat input and measurement of ferrite content is certainly not enough to inform about the corrosion resistance of the weld region. It is suggested to also include information about the peak weld current density and the weld width, since these are related to the microstructure evolution during welding, which influence generation of deleterious $\mathrm{Cr}$ depleted zones.

\section{Conclusions}

The corrosion performance of lean grade 2101 duplex stainless steel, welded by two ASME qualified welding procedure specifications, were assessed. From the results the following conclusions can be drawn:

- WPS 1 with heat input of 1.6-1.9 kJ/mm and low current $(140 \mathrm{~A})$ demonstrated better corrosion performance compared to WPS 2 with heat input of $1.0-1.2 \mathrm{~kJ} / \mathrm{mm}$ and high current (275 A).

- The weld face (WF) had higher corrosion resistance with the highest PREN, due to alloying elements retention of the weld consumable in the ferrite phase. This region is recommended for exposure to the corrosive environment.

- The fusion line (FL) showed the lowest corrosion resistance. Chromium nitrides were present in the fusion line for both welding procedures, precipitated within ferrite grains and at interphase boundaries.

- A relationship between microstructure features within the weld regions, with Voltapotential differences, ferrite content, microstructure appearance, DOS and the critical pitting potential was apparent.

- The corrosion performance of the micro-regions should be used to complement the ASME requirements to qualify these welding procedures. 


\section{Acknowledgments}

The authors would like to thank the São Paulo Research Foundation (FAPESP) for providing financial support for this research (Proc. no. 2016/08439-0).

\section{References}

1. Lippold, J.C., and D.J. Kotecki, Welding Metallurgy and Weldability of Stainless Steels (John Wiley and Sons Inc, 2005).

2. Olsson, J., and M. Snis, Desalination 205 (2007): pp. 104-113.

3. Westin, E.M., and S. Hertzman, Weld. World 58 (2014): pp. 143-160.

4. Westin, E.M., "Microstructure and Properties of Welds in the Lean Duplex Stainless Steel LDX 2101," Royal Institute of Technology, 2010.

5. Westin, E.M., B. Brolund, and S. Hertzman, Steel Res. Int. 79 (2016): pp. 473-481.

6. Johansson, M.M., E.M. Westin, J. Oliver, and R.F.A. Pettersson, Weld. World 55 (2011): pp. 19-27.

7. Westin, E.M., E. Keehan, M. Ström, and B. von Brömssen, "Laser Welding of a Lean Duplex Stainless Steel," in Int. Congr. Appl. Lasers Electro-Optics (2018), pp. 335-344.

8. Westin, E.M., M.M. Johansson, and R.F.A. Pettersson, Weld. World 57 (2013): pp. 467476.

9. Westin, E.M., and A. Fellman, J. Laser Appl. 22 (2010): pp. 150-158.

10. Westin, E.M., C.O.A. Olsson, and S. Hertzman, Corros. Sci. 50 (2008): pp. 2620-2634.

11. Sicupira, D.C., G.S. Frankel, and V. de F. C. Lins, Mater. Corros. 67 (2016): pp. 440-448.

12. Zanotto, F., V. Grassi, M. Merlin, A. Balbo, and F. Zucchi, Corros. Sci. 94 (2015): pp. 3847.

13. ASME IX, "Qualification Standard for Welding, Brazing and Fusing Procedures," in ASME Boil. Press. Vessel Code (2015).

14. Tan, H., Z. Wang, Y. Jiang, Y. Yang, B. Deng, H. Song, and J. Li, Corros. Sci. 55 (2012): pp. 368-377.

15. Chen, L., H. Tan, Z. Wang, J. Li, and Y. Jiang, Corros. Sci. 58 (2012): pp. 168-174.

16. Silva, R., L.F.S. Baroni, C.L. Kugelmeier, M.B.R. Silva, S.E. Kuri, and C.A.D. Rovere, Corros. Sci. 116 (2017): pp. 66-73.

17. Gao, J., Y. Jiang, B. Deng, W. Zhang, C. Zhong, and J. Li, Electrochim. Acta 54 (2009): pp. 
5830-5835.

18. Deng, B., Y. Jiang, J. Xu, T. Sun, J. Gao, L. Zhang, W. Zhang, and J. Li, Corros. Sci. 52 (2010): pp. 969-977.

19. Yang, Y., B. Yan, J. Li, and J. Wang, Corros. Sci. 53 (2011): pp. 3756-3763.

20. Chen, L., H. Tan, Z. Wang, J. Li, and Y. Jiang, Corros. Sci. 58 (2012): pp. 168-174.

21. Zhang, Z., H. Jing, L. Xu, Y. Han, and L. Zhao, Mater. Des. 109 (2016): pp. 670-685.

22. Aguiar, I.V., D.P. Escobar, D.B. Santos, and P.J. Modenesi, Rev. Mater. 20 (2015): pp. 212-226.

23. Karayan, A.I., and H. Castaneda, Eng. Fail. Anal. 44 (2014): pp. 351-362.

24. Xiong, J., S. Agarwala, M.Y. Tan, and M. Forsyth, Corrosion 71 (2015): pp. 1248-1256.

25. Martin, F., C. Garcia, P. Tiedra, Y. Blanco, and M. Lopez, Corros. Eng. Sci. Technol. 43 (2008): pp. 343-352.

26. Guilherme, L.H., A. Benedetti, and C. Fugivara, Corrosion 75 (2018): pp. 340-348.

27. Lo, I.H., Y. Fu, C.J. Lin, and W.T. Tsai, Corros. Sci. 48 (2006): pp. 696-708.

28. Sicupira, D.C., R.C. Junior, A.Q. Bracarense, G.S. Frankel, and V. de F. Cunha Lins, Mater. Res. J. Mater. 20 (2017): pp. 161-167.

29. Reccagni, P.; Guilherme, L.H.; Lu, Q.; Gittos, M.; Engelberg, D.L., Corros. Sci. (2019): p. (accepted).

30. Femenia, M., J. Pan, and C. Leygraf, J. Electrochem. Soc. 151 (2004): p. B581.

31. Örnek, C., and D.L. Engelberg, Corros. Sci. 99 (2015): pp. 164-171.

32. Hashimoto, T., D.L. Engelberg, J. Walton, T.L. Ladwein, C. Örnek, and S.B. Lyon, J. Electrochem. Soc. 164 (2017): pp. C207-C217.

33. Silva, R., L.F.S. Baroni, M.B.R. Silva, C.R.M. Afonso, S.E. Kuri, and C.A.D. Rovere, Mater. Charact. 114 (2016): pp. 211-217.

34. Ramirez, A.J., J.C. Lippold, and S.D. Brandi, Metall. Mater. Trans. A Phys. Metall. Mater. Sci. 34 (2003): pp. 1575-1597.

35. Mélo, E.B. de, R. Magnabosco, and C. de Moura Neto, Mater. Res. 16 (2013): pp. $1336-$ 1343.

36. Magnabosco, R., and N. Alonso-Falleiros, Corrosion 61 (2005): pp. 130-136.

37. Li, W., and J. Luo, Electrochem. Commun. 1 (1999): pp. 349-353.

38. Soltis, J., Corros. Sci. 90 (2015): pp. 5-22. 
39. Ha, H.-Y., M.-H. Jang, T.-H. Lee, and J. Moon, Corros. Sci. 89 (2014): pp. 154-162.

40. Hsieh, C.-C., and W. Wu, ISRN Metall. 2012 (2012): pp. 1-16.

41. Tan, H., Y. Jiang, B. Deng, T. Sun, J. Xu, and J. Li, Mater. Charact. 60 (2009): pp. 10491054.

42. Guilherme, L.H., C.A. Della Rovere, S.E. Kuri, and M.F. de Oliveira, Weld. Int. 30 (2016): pp. 268-276.

43. Guilherme, L.H.; Rovere, C.A.D.; Kuri, S.E.; Oliveira, M.F., Soldag. e Insp. 19 (2014): pp. $42-50$.

44. A Hosseini, V., L. Karlsson, D. Engelberg, and S. Wessman, Weld. World 62 (2018): pp. 517-533.

45. Engelberg, D.L., F. Léonard, S.A. McDonald, P.J. Withers, A. Prajapati, and C. Örnek, Npj Mater. Degrad. 2 (2018): pp. 1-15.

46. Garzón, C.M., C.A. Serna, S.D. Brandi, and A.J. Ramirez, J. Mater. Sci. 42 (2007): pp. 9021-9029.

47. Tan, H., Z. Wang, Y. Jiang, D. Han, J. Hong, L. Chen, L. Jiang, and J. Li, Corros. Sci. 53 (2011): pp. 2191-2200. 


\section{Figures and Captions (colours required for all figures)}

(a)

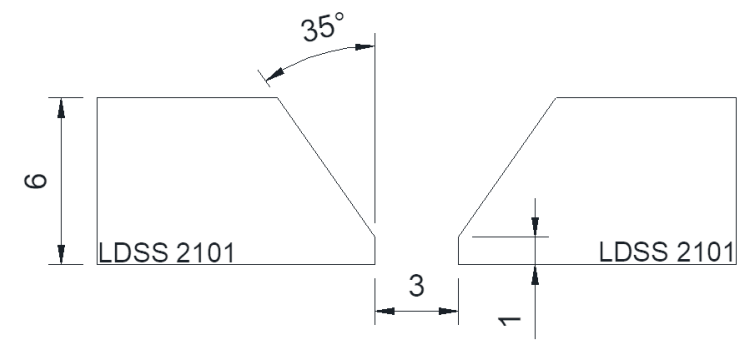

(b)

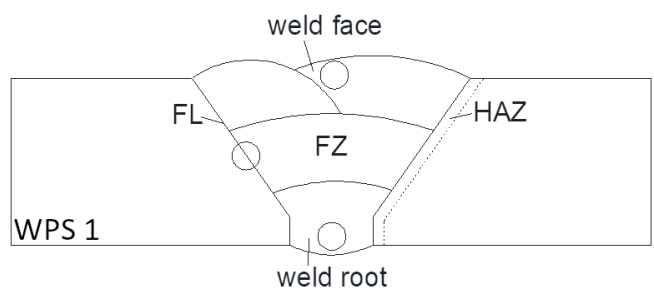

(c)

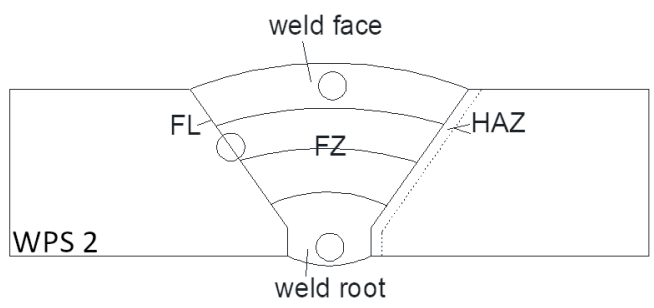

Microcapillary of the microcell

Figure 1. Schematic illustration of the welded joint, showing detail of the bevel, the weld passes, and the micro-capillary coupling points ( $F Z$ = fusion zone, $\mathrm{HAZ}=$ heat affected zone, $\mathrm{FL}=$ fusion line, $\mathrm{LDSS}=$ Lean Duplex Stainless Steel). 

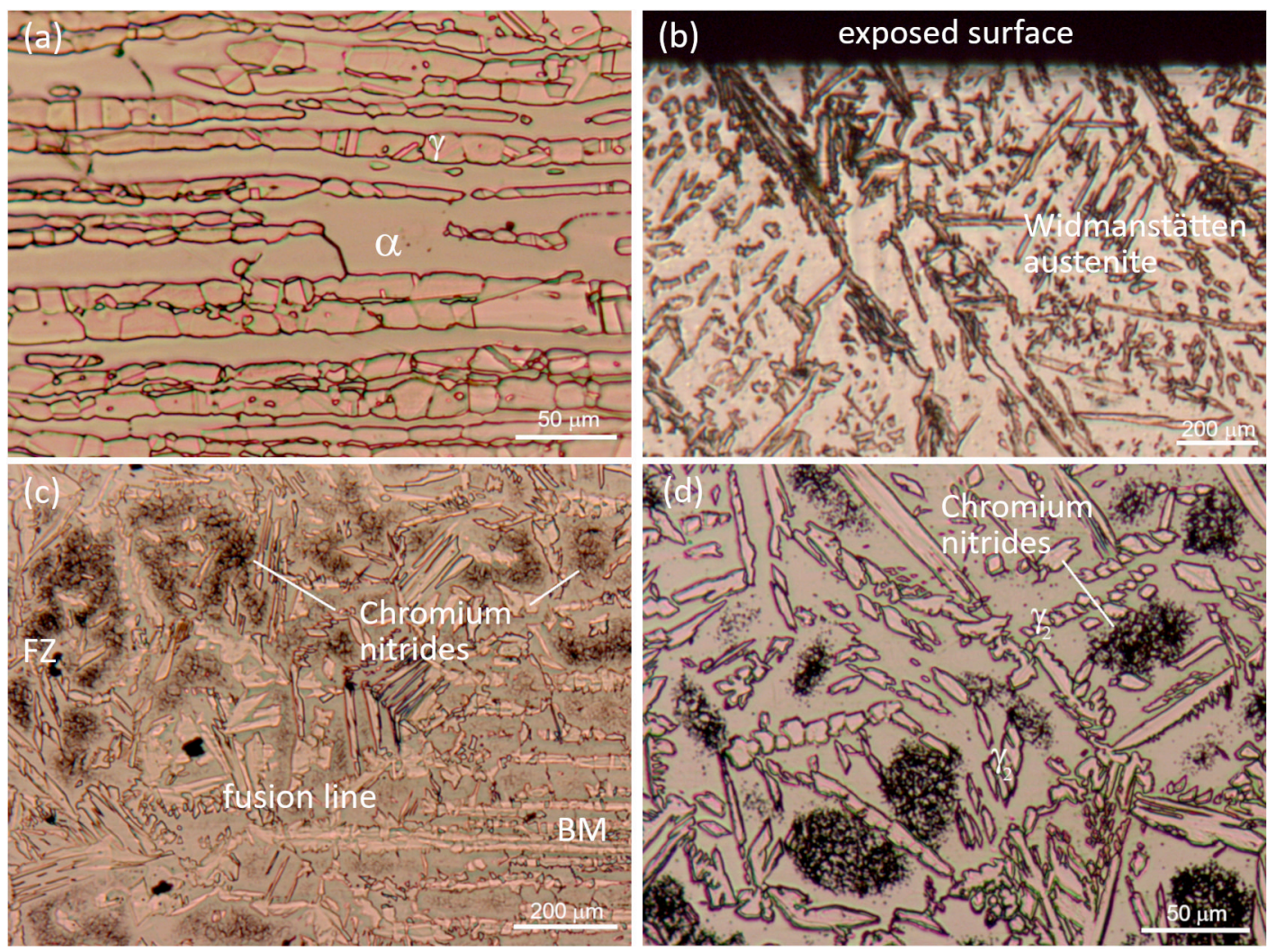

Figure 2. Optical microscopy images of: (a) base metal (BM), (b) weld face region showing Widmanstätten austenite, (c) fusion line (FL) showing Cr-nitride containing zones and (d) the weld root (WR) with secondary austenite and $\mathrm{Cr}$-depleted zones.

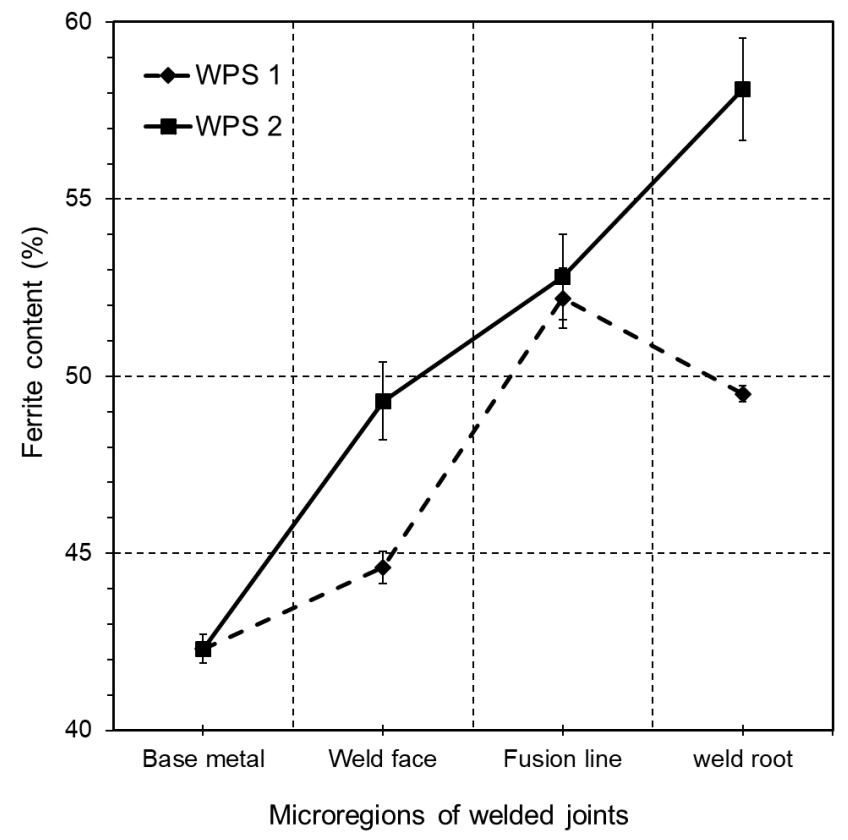

Figure 3. Quantitation of the ferrite content on the weld micro-regions of WPS 1 and WPS 2, measured by ferrite-scope. The error bars is standard deviation of 10 measurements. 


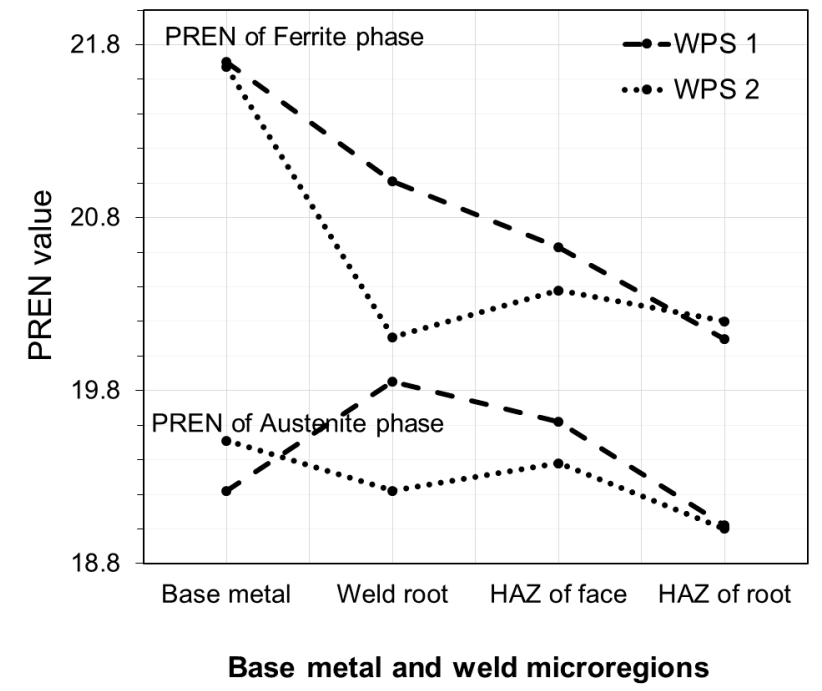

Figure 4. Weld regions and their PREN values from Table 3. 

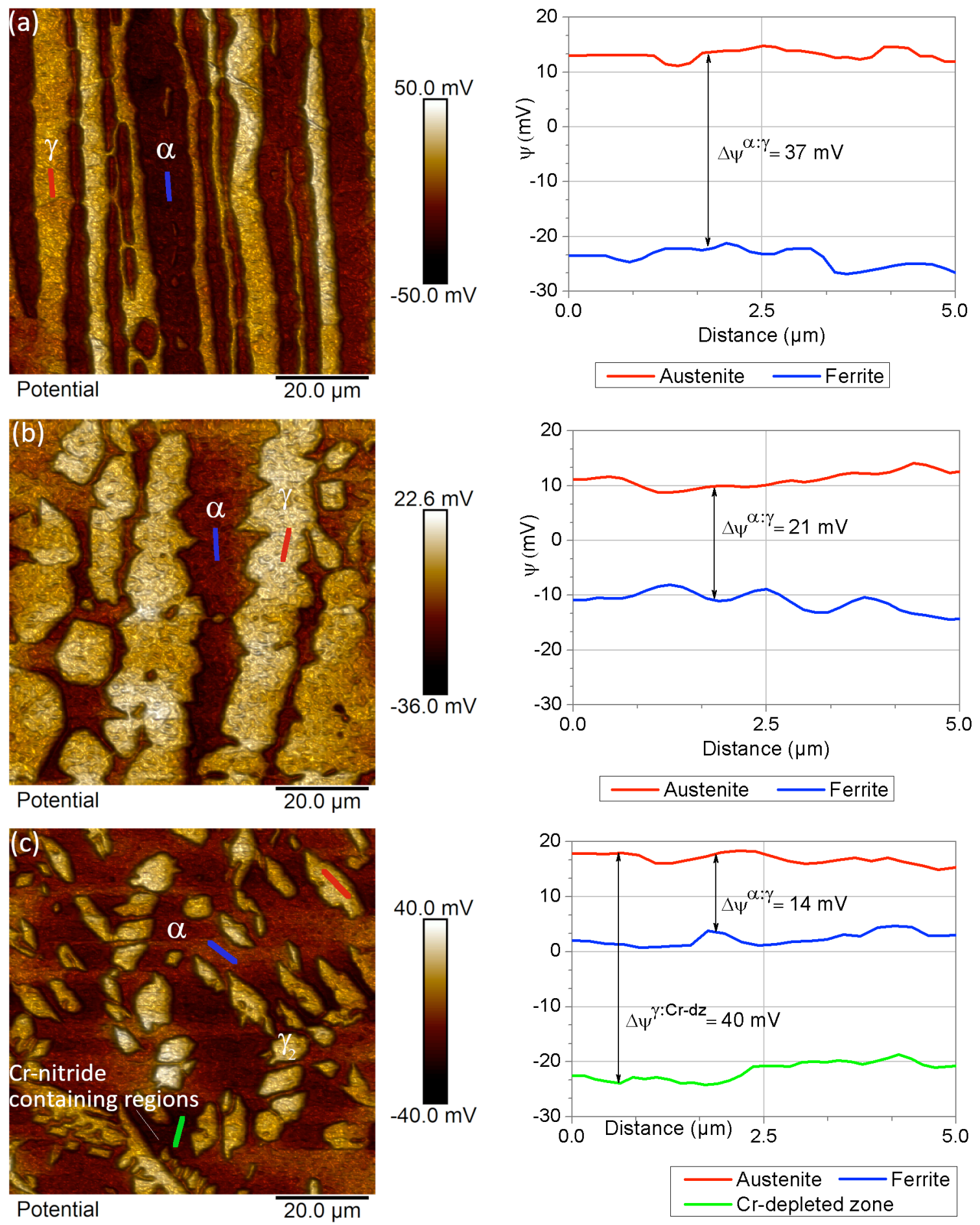

Figure 5. Volta potential maps for (a) base metal, (b) weld face and (c) fusion line. 


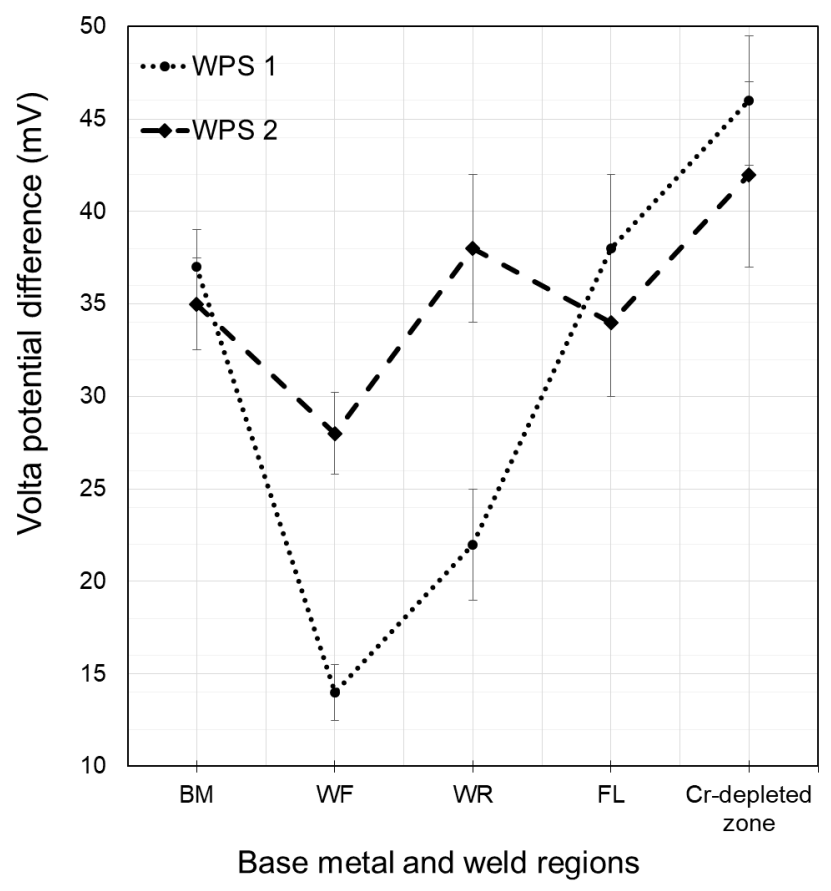

Figure 6. Volta potential difference between ferrite and austenite measured for all weld regions of WPS 1 and WPS 2 (BM=base metal; WF=weld face; $W R=$ weld root; $F L=$ fusion line). 

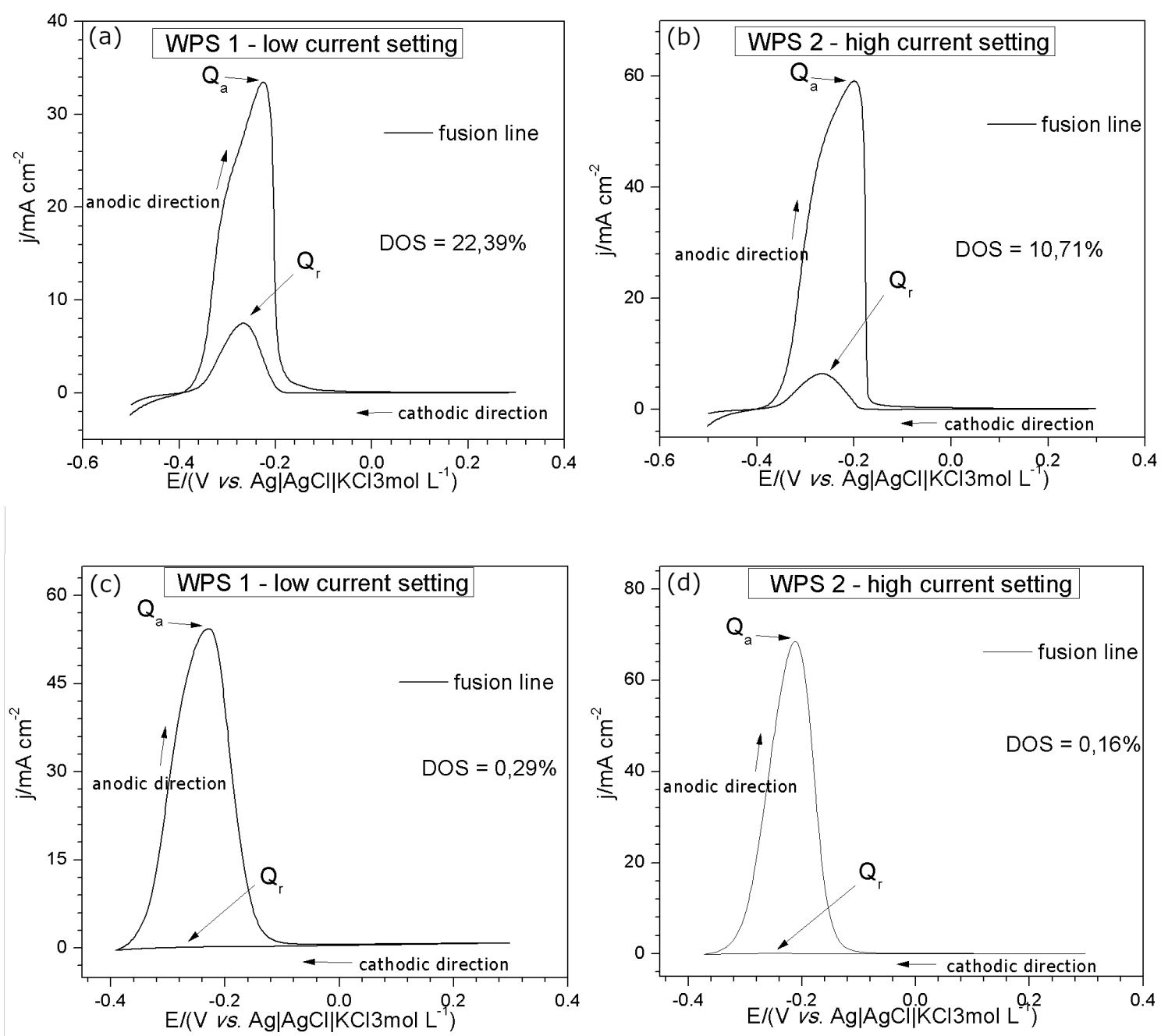

Figure 7. DL-EPR curves of the fusion line obtained for (a) WPS 1 and (b) WPS 2 in $0.5 \mathrm{~mol} \mathrm{~L}^{-1} \mathrm{H}_{2} \mathrm{SO}_{4}+$ $0.01 \mathrm{~mol} \mathrm{~L}^{-1} \mathrm{KSCN}$, and (c) WPS 1 and (d) WPS 2 in $2.0 \mathrm{~mol} \mathrm{~L}^{-1} \mathrm{H}_{2} \mathrm{SO}_{4}+0.5 \mathrm{~mol} \mathrm{~L}^{-1} \mathrm{HCl}$. 

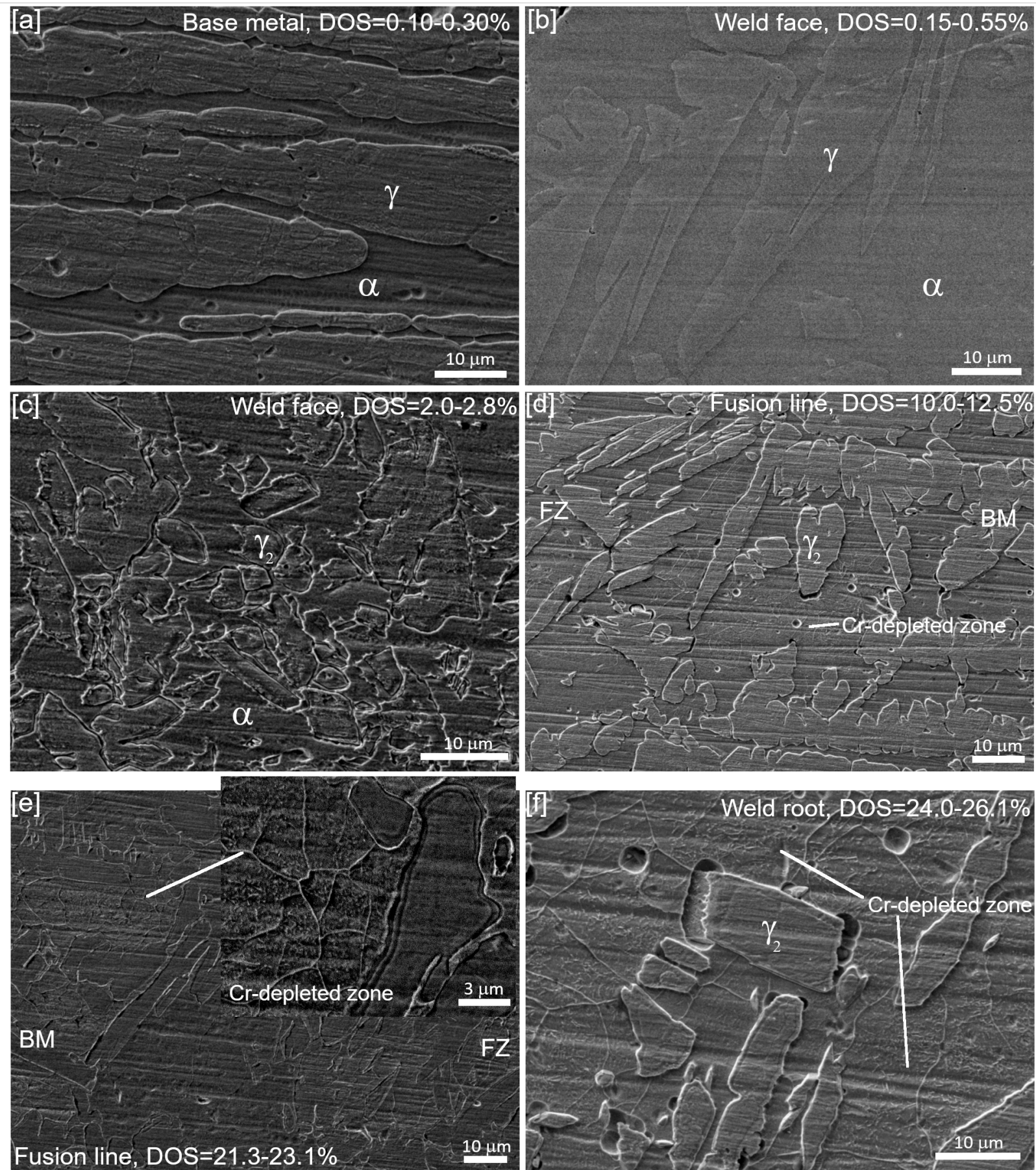

Figure 8. SEM micrographs of the surface of LDSS 2101 after DL-EPR tests: (a) base metal, (b and c) weld face, ( $d$ and e) fusion line and (f) weld root. 

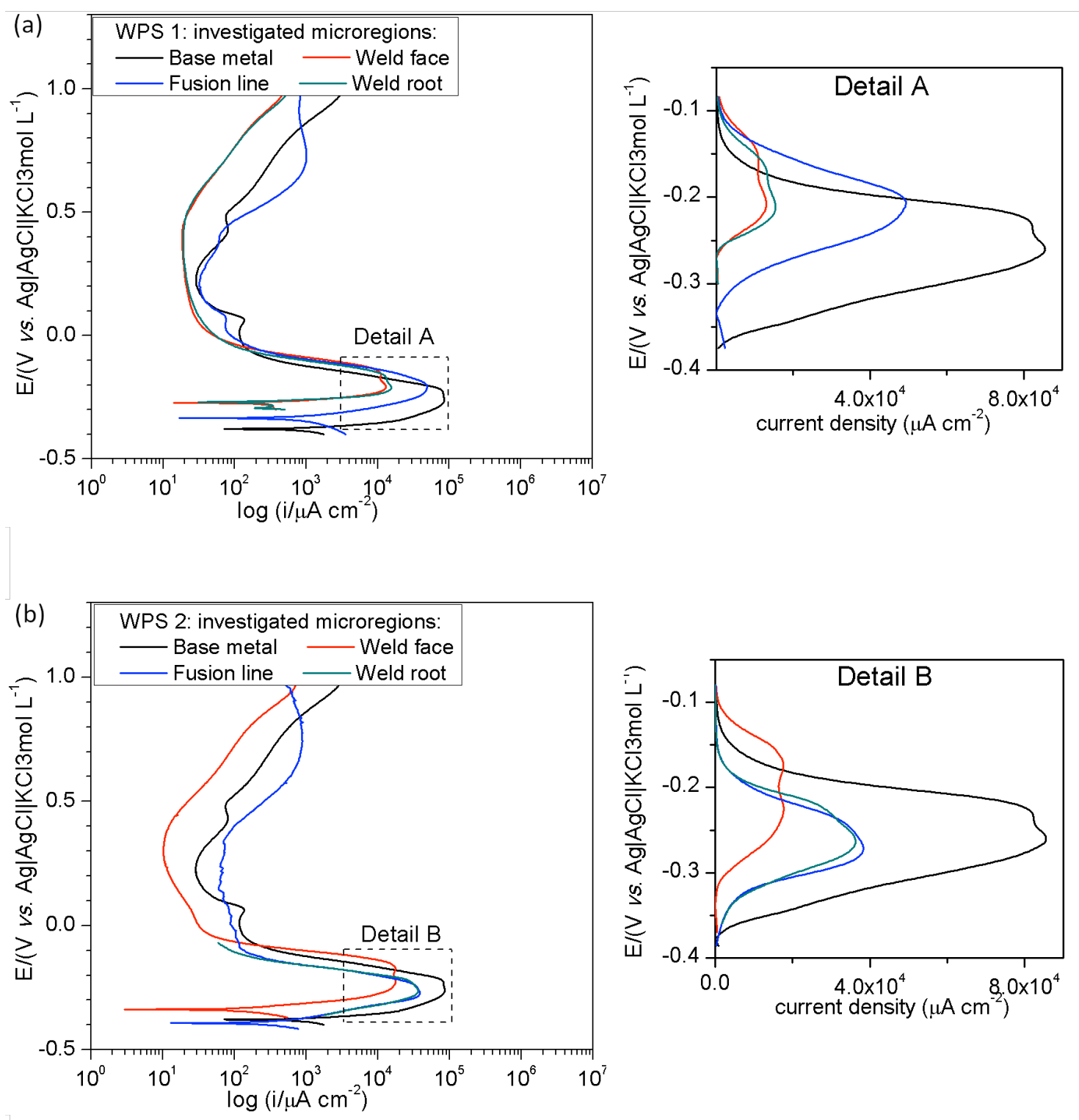

Figure 9. Potentio-dynamic polarization curves of LDX 2101 welds obtained in $2 \mathrm{~mol} \mathrm{~L}^{-1} \mathrm{H}_{2} \mathrm{SO}_{4}+0.5 \mathrm{~mol}$ $\mathrm{L}^{-1} \mathrm{HCl}$ aqueous solution and the potential range of the active-to-passive transition regions of (a) WPS 1 and (b) WPS 2. 

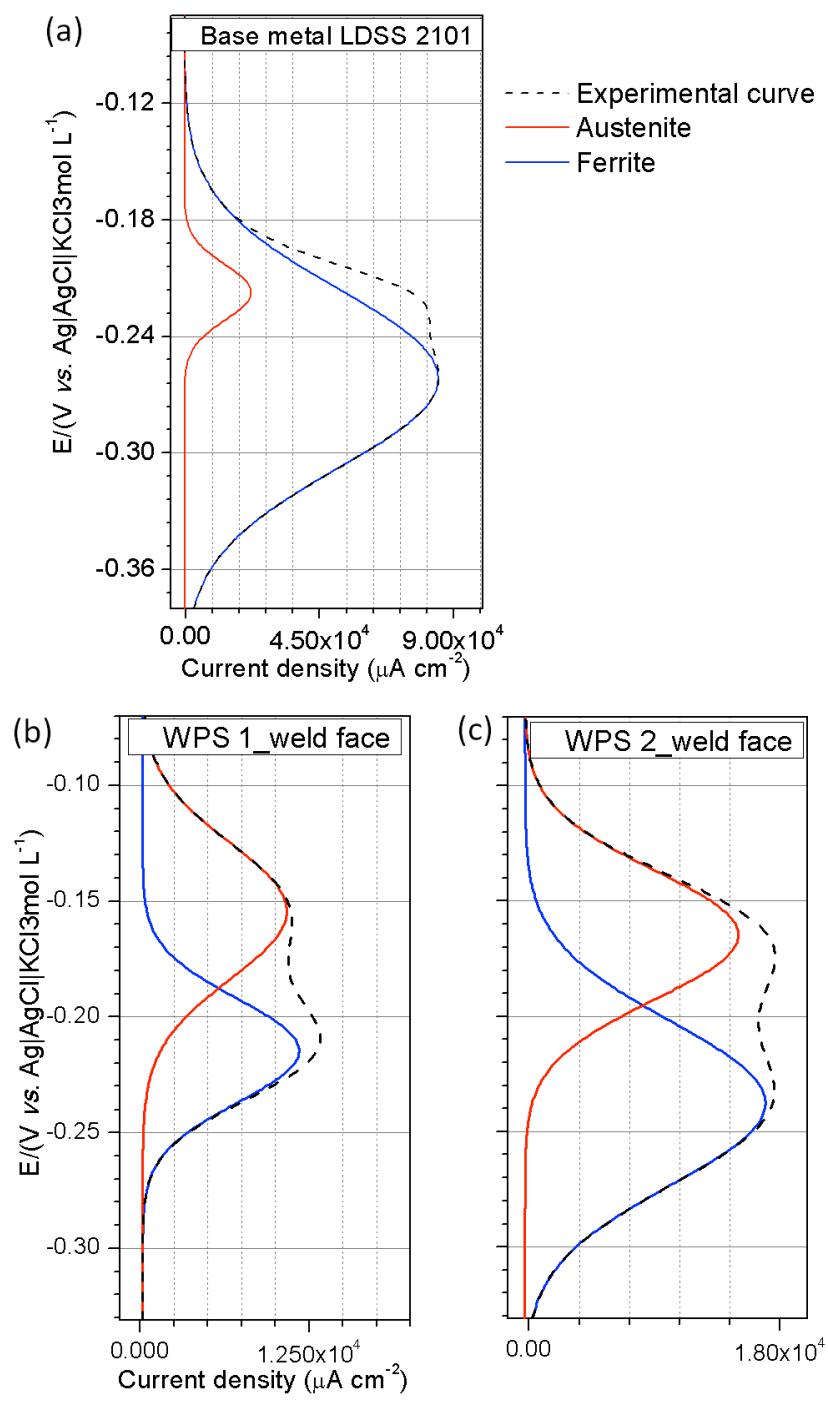

(c) WPS 2 weld face

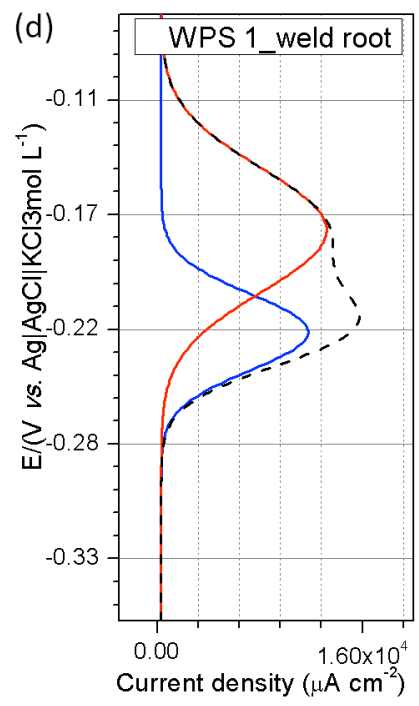

(e) WPS 2 weld root

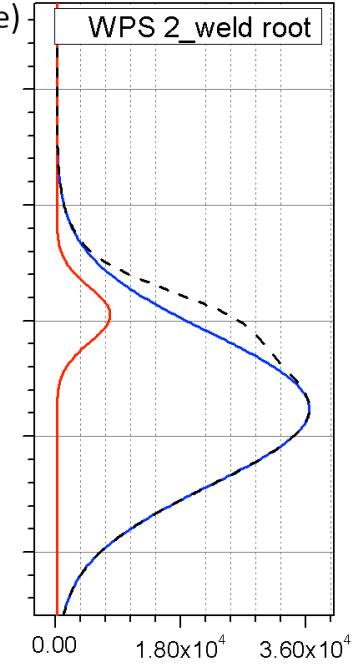

Figure 10. Gaussian deconvolution of the potentiodynamic polarization curves obtained in $2 \mathrm{~mol} \mathrm{~L}^{-1}$ $\mathrm{H}_{2} \mathrm{SO}_{4}+0.5 \mathrm{~mol} \mathrm{~L}^{-1} \mathrm{HCl}$ aqueous solution showing the activation regions for the (a) base metal LDSS 2101, (b) weld face of the WPS 1, (c) weld face of the WPS 2, (d) weld root of the WPS 1 and (e) weld root of the WPS 2. 


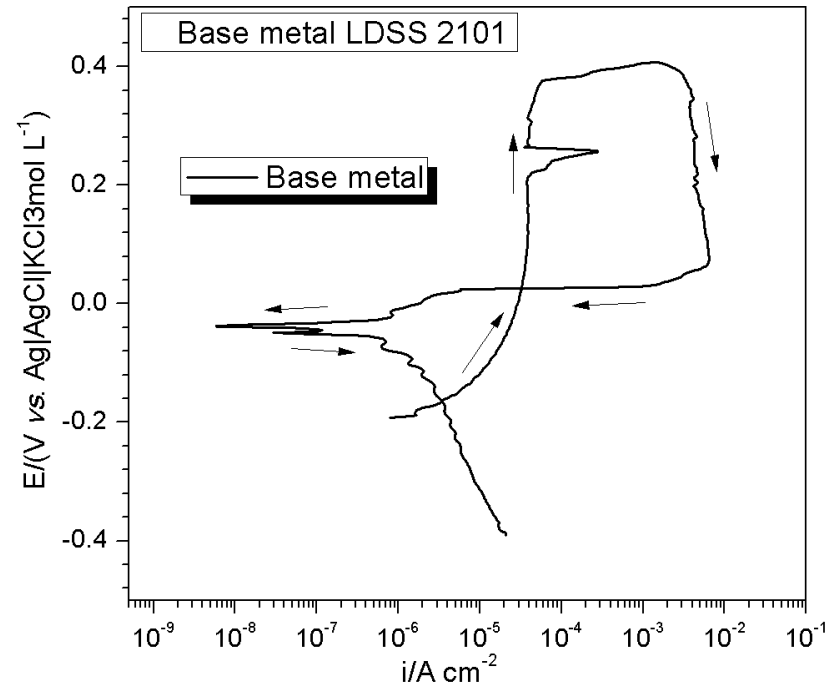

(a)

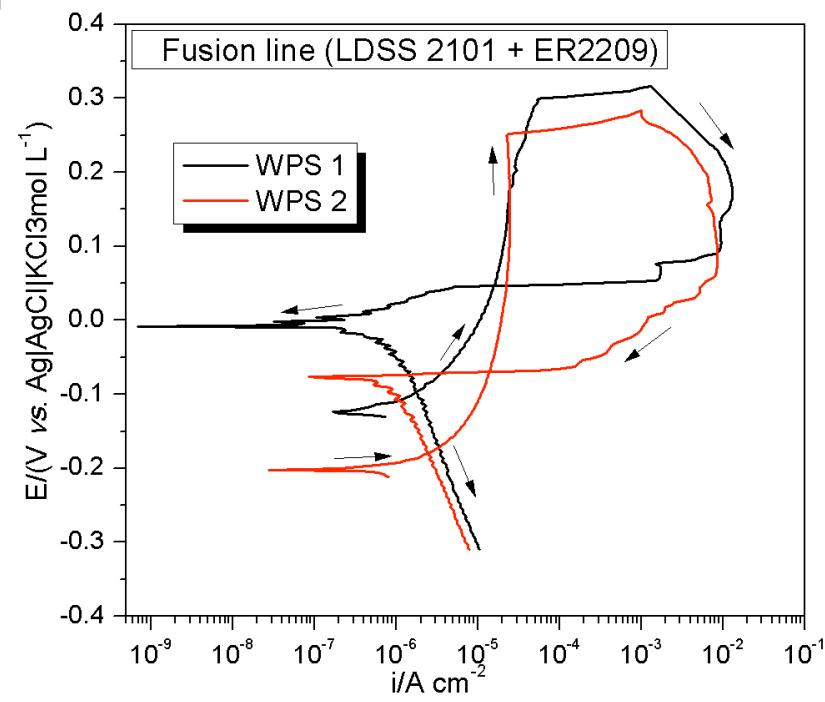

(c)

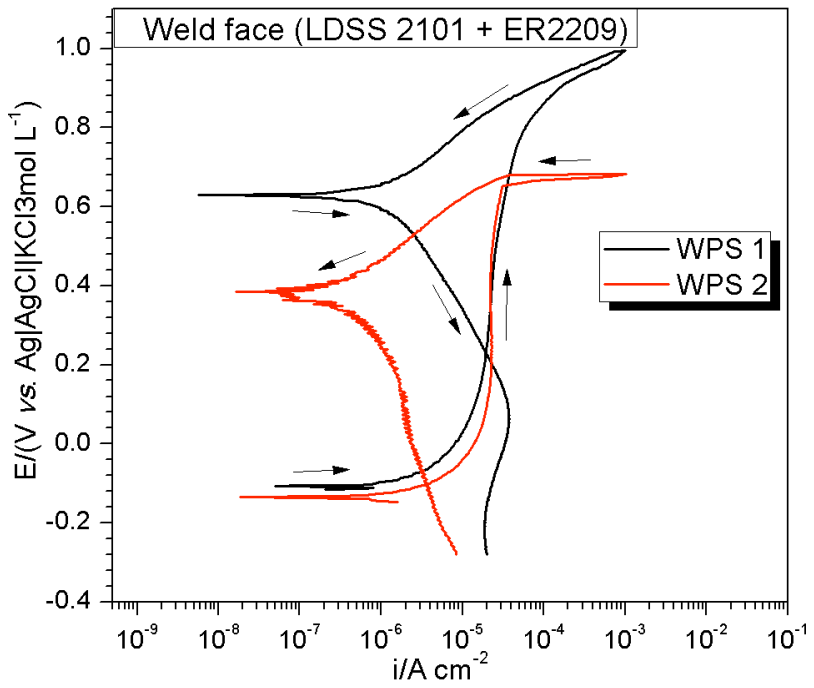

(b)

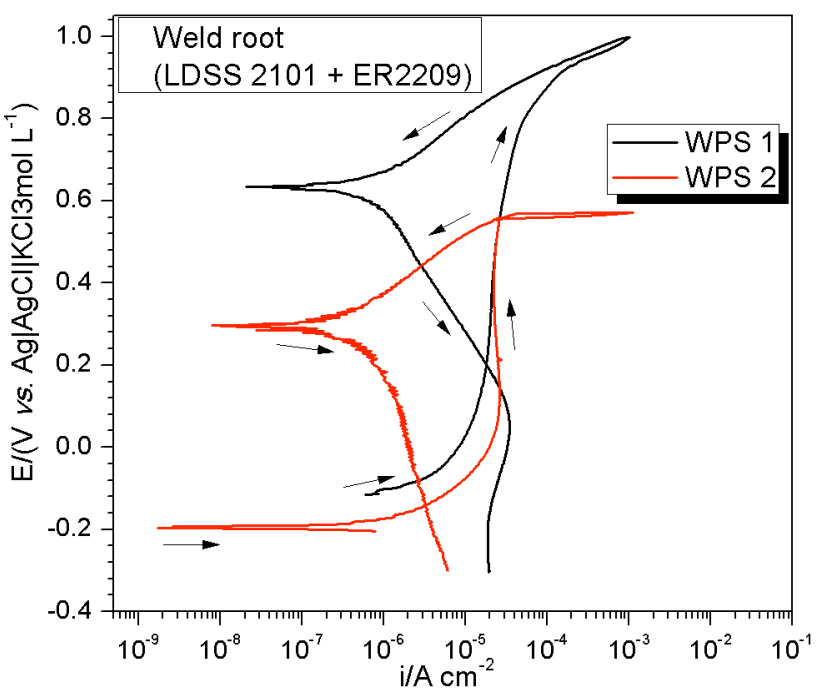

(d)

Figure 11. CPP curves obtained in 3.5\% NaCl for the studied regions: (a) base metal LDX 2101, (b) weld face, (c) fusion line and (d) weld root. 


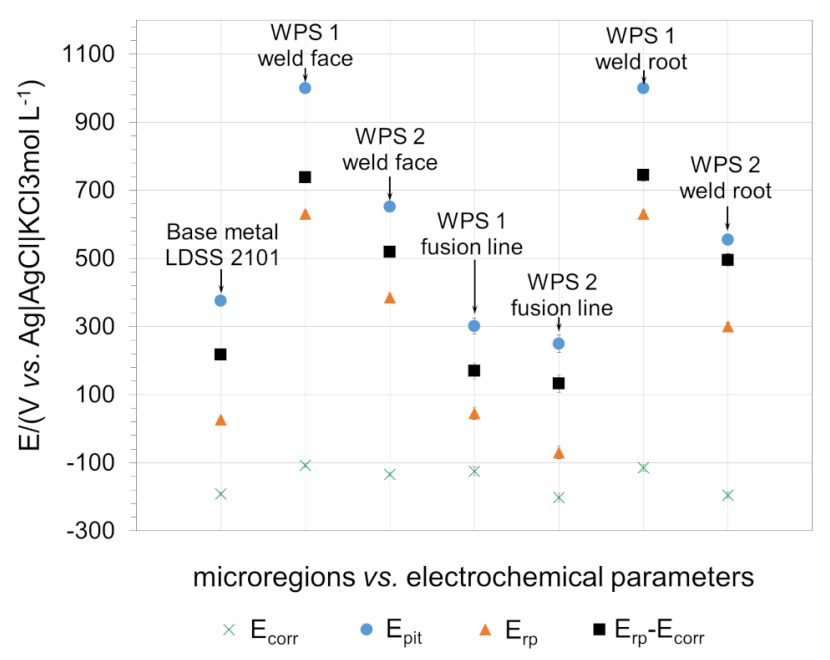

Figure 12. Quantitative determination of electrochemical parameters from CPP tests.

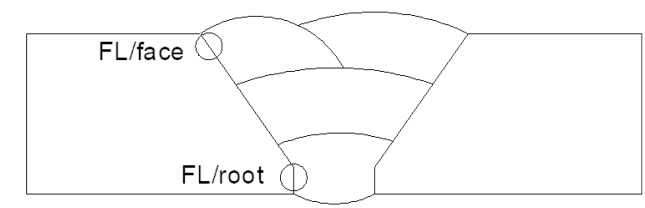

Microcapillary of the microcell

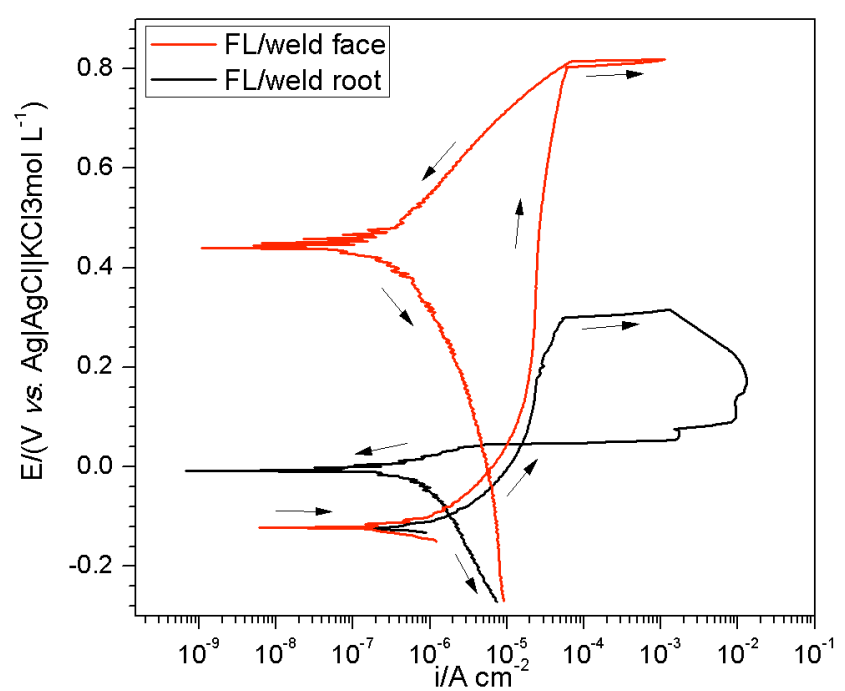

Figure 13. Cyclic potentiodynamic polarization curves of fusion line microregions. 


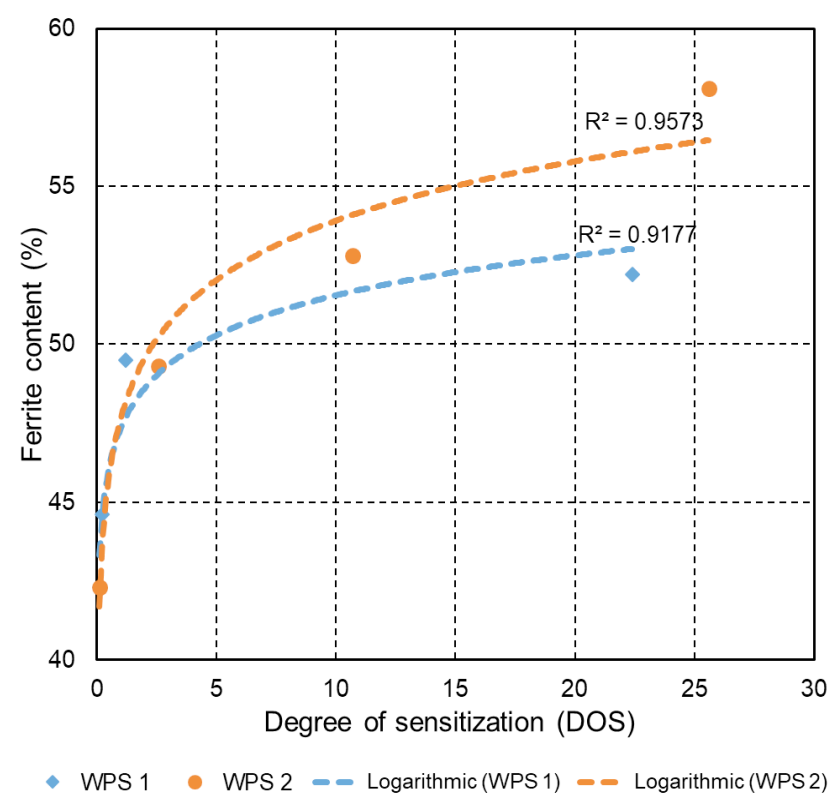

Figure 14. Correlation analysis between DOS and ferrite content. 
Figure 1. Schematic illustration of the welded joint, showing detail of the bevel, the weld passes, and the micro-capillary coupling points ( $F Z=$ fusion zone, $H A Z=$ heat affected zone, $F L=$ fusion line, $L D S S=$ Lean Duplex Stainless Steel).

Figure 2. Optical microscopy images of: (a) base metal (BM), (b) weld face region showing Widmanstätten austenite, (c) fusion line (FL) showing Cr-nitride containing zones and (d) the weld root (WR) with secondary austenite and $\mathrm{Cr}$-depleted zones.

Figure 3. Quantitation of the ferrite content on the weld micro-regions of WPS 1 and WPS 2, measured by ferrite-scope. The error bars is standard deviation of 10 measurements.

Figure 4. Weld regions and their PREN values from Table 3.

Figure 5. Volta potential maps for (a) base metal, (b) weld face and (c) fusion line.

Figure 6. Volta potential difference between ferrite and austenite measured for all weld regions of WPS 1 and WPS 2 (BM=base metal; WF=weld face; WR=weld root; FL=fusion line).

Figure 7. DL-EPR curves of the fusion line obtained for (a) WPS 1 and (b) WPS 2 in $0.5 \mathrm{~mol} \mathrm{~L}^{-1} \mathrm{H}_{2} \mathrm{SO}_{4}+$ $0.01 \mathrm{~mol} \mathrm{~L}^{-1} \mathrm{KSCN}$, and (c) WPS 1 and (d) WPS 2 in $2.0 \mathrm{~mol} \mathrm{~L}^{-1} \mathrm{H}_{2} \mathrm{SO}_{4}+0.5 \mathrm{~mol} \mathrm{~L}^{-1} \mathrm{HCl}$.

Figure 8. SEM micrographs of the surface of LDSS 2101 after DL-EPR tests: (a) base metal, (b and c) weld face, ( $d$ and e) fusion line and (f) weld root.

Figure 9. Potentio-dynamic polarization curves of LDX 2101 welds obtained in $2 \mathrm{~mol} \mathrm{~L}^{-1} \mathrm{H}_{2} \mathrm{SO}_{4}+0.5$ mol $\mathrm{L}^{-1} \mathrm{HCl}$ aqueous solution and the potential range of the active-to-passive transition regions of (a) WPS 1 and (b) WPS 2.

Figure 10. Gaussian deconvolution of the potentiodynamic polarization curves obtained in $2 \mathrm{~mol} \mathrm{~L}^{-1}$ $\mathrm{H}_{2} \mathrm{SO}_{4}+0.5 \mathrm{~mol} \mathrm{~L}^{-1} \mathrm{HCl}$ aqueous solution showing the activation regions for the (a) base metal LDSS 2101, (b) weld face of the WPS 1, (c) weld face of the WPS 2, (d) weld root of the WPS 1 and (e) weld root of the WPS 2 .

Figure 11. CPP curves obtained in 3.5\% NaCl for the studied regions: (a) base metal LDX 2101, (b) weld face, (c) fusion line and (d) weld root.

Figure 12. Quantitative determination of electrochemical parameters from CPP tests.

Figure 13. Cyclic potentiodynamic polarization curves of fusion line microregions.

Figure 14. Correlation analysis between DOS and ferrite content. 
Table 1. Chemical compositions (wt.\%) of UNS S32101 and ER2209.

\begin{tabular}{|c|c|c|c|c|c|c|c|c|c|c|}
\hline \multirow{2}{*}{ Sample } & \multicolumn{10}{|c|}{ Elements (wt. \%) } \\
\hline & $\mathrm{C}$ & $\mathrm{Cr}$ & $\mathrm{Ni}$ & Mo & $\mathrm{Mn}$ & $\mathrm{P}$ & S & $\mathrm{Si}$ & N & $\mathrm{Cu}$ \\
\hline UNS S32101 & 0.019 & 21.32 & 1.15 & 0.19 & 4.87 & 0.024 & 0.001 & 0.73 & 0.22 & 0.53 \\
\hline ER 2209 & 0.020 & 22.90 & 8.6 & 3.20 & 1.6 & 0.017 & 0.001 & 0.4 & 0.16 & 0.10 \\
\hline
\end{tabular}

Table 2. TIG welding conditions to the (a) WPS 1, and (b) WPS 2.

(a)

\begin{tabular}{c|c|c|c|c|c}
\hline $\begin{array}{c}\text { Weld } \\
\text { pass }\end{array}$ & Current (A) & Voltage (V) & $\begin{array}{c}\text { Travel } \\
\text { speed } \\
(\mathrm{mm} / \mathrm{min})\end{array}$ & $\begin{array}{c}\text { Heat input } \\
\left(\mathrm{KJ} . \mathrm{mm}^{-1}\right)\end{array}$ & $\begin{array}{c}\text { Width of } \\
\text { weld } \\
(\mathrm{mm})\end{array}$ \\
\hline 1 & $120 \pm 1$ & $15.9 \pm 0.1$ & $71.4 \pm 10$ & $1.60 \pm 0.2$ & 4 \\
\hline 2 & $140 \pm 1$ & $14.8 \pm 0.1$ & $50.4 \pm 6$ & $2.49 \pm 0.1$ & 8 \\
\hline 3 & $142 \pm 1$ & $15.3 \pm 0.1$ & $72 \pm 11$ & $1.78 \pm 0.1$ & 6 \\
\hline 4 & $142 \pm 1$ & $15.8 \pm 0.1$ & $68 \pm 6$ & $1.97 \pm 0.1$ & 6 \\
\hline
\end{tabular}

(b)

\begin{tabular}{c|c|c|c|c|c}
\hline $\begin{array}{c}\text { Weld } \\
\text { pass }\end{array}$ & Current (A) & Voltage (V) & $\begin{array}{c}\text { Travel } \\
\text { speed } \\
(\mathrm{mm} / \mathrm{min})\end{array}$ & $\begin{array}{c}\text { Heat input } \\
\left(\mathrm{KJ} . \mathrm{mm}^{-1}\right)\end{array}$ & $\begin{array}{c}\text { Width of } \\
\text { weld } \\
(\mathrm{mm})\end{array}$ \\
\hline 1 & $185 \pm 1$ & $16.0 \pm 0.1$ & $150 \pm 9$ & $1.18 \pm 0.2$ & 5 \\
\hline 2 & $250 \pm 1$ & $17.1 \pm 0.1$ & $222 \pm 11$ & $1.16 \pm 0.1$ & 8 \\
\hline 3 & $275 \pm 1$ & $20.5 \pm 0.2$ & $286 \pm 12$ & $1.18 \pm 0.2$ & 9 \\
\hline 4 & $276 \pm 1$ & $19.7 \pm 0.1$ & $332 \pm 12$ & $0.98 \pm 0.1$ & 12 \\
\hline
\end{tabular}

Contact tip to work distance (CTWD): $\pm 10 \mathrm{~mm}$.

Shielding gas / flow rate / Polarity: 100\% Ar / $15 \mathrm{~L} \mathrm{~min}^{-1} /$ DCEN(-). 
Table 3. Variance in chemical composition of austenite/ferrite for the investigated microregions.

\begin{tabular}{|c|c|c|c|c|c|c|c|c|c|c|c|}
\hline \multirow{2}{*}{\multicolumn{2}{|c|}{$\begin{array}{c}\text { chemical composition of } \\
\text { phases }\end{array}$}} & \multicolumn{5}{|c|}{ WPS 1} & \multicolumn{5}{|c|}{ WPS 2} \\
\hline & & \multicolumn{5}{|c|}{ Elements \% (SD) } & \multicolumn{5}{|c|}{ Elements \% (SD) } \\
\hline Region & Phase & $\mathrm{Cr}$ & Mo & $\mathrm{Ni}$ & $\mathrm{Mn}$ & PREN & $\mathrm{Cr}$ & Mo & $\mathbf{N i}$ & Mn & PREN \\
\hline \multirow{2}{*}{$\begin{array}{l}\text { Base metal } \\
\text { (BM) }\end{array}$} & Ferrite & $\begin{array}{l}20.41 \\
(<0.1)\end{array}$ & $\begin{array}{c}0.39 \\
(0.12)\end{array}$ & $\begin{array}{c}1.3 \\
(<0.1)\end{array}$ & $\begin{array}{c}4.17 \\
(<0.1)\end{array}$ & 21.70 & $\begin{array}{l}20.12 \\
(0.24)\end{array}$ & $\begin{array}{c}0.47 \\
(0.11)\end{array}$ & $\begin{array}{c}1.29 \\
(<0.1)\end{array}$ & $\begin{array}{c}4.52 \\
(0.13)\end{array}$ & 21.67 \\
\hline & Austenite & $\begin{array}{l}18.69 \\
(0.23)\end{array}$ & $\begin{array}{c}0.16 \\
(<0.1)\end{array}$ & $\begin{array}{c}1.70 \\
(<0.1)\end{array}$ & $\begin{array}{c}4.78 \\
(<0.1)\end{array}$ & 19.22 & $\begin{array}{l}19.08 \\
(0.25)\end{array}$ & $\begin{array}{c}0.13 \\
(<0.1)\end{array}$ & $\begin{array}{c}1.89 \\
(0.12)\end{array}$ & $\begin{array}{c}5.28 \\
(0.17)\end{array}$ & 19.51 \\
\hline \multirow{2}{*}{$\begin{array}{l}\text { Weld face } \\
\text { (WF) }\end{array}$} & Ferrite & $\begin{array}{l}23.51 \\
(0.12)\end{array}$ & $\begin{array}{c}3.11 \\
(0.22)\end{array}$ & $\begin{array}{c}7.31 \\
(0.32)\end{array}$ & $\begin{array}{c}1.37 \\
(0.30)\end{array}$ & 33.77 & $\begin{array}{c}23.34 \\
(0.2)\end{array}$ & $\begin{array}{c}2.95 \\
(0.19)\end{array}$ & $\begin{array}{c}7.44 \\
(0.15)\end{array}$ & $\begin{array}{c}1.13 \\
(0.12)\end{array}$ & 33.08 \\
\hline & Austenite & $\begin{array}{c}22.0 \\
(0.33)\end{array}$ & $\begin{array}{c}2.55 \\
(0.27)\end{array}$ & $\begin{array}{c}8.67 \\
(0.35)\end{array}$ & $\begin{array}{c}1.76 \\
(0.11)\end{array}$ & 30.42 & $\begin{array}{l}22.65 \\
(0.23)\end{array}$ & $\begin{array}{c}2.71 \\
(0.16)\end{array}$ & $\begin{array}{c}8.25 \\
(0.38)\end{array}$ & $\begin{array}{c}2.32 \\
(0.15)\end{array}$ & 31.59 \\
\hline \multirow{2}{*}{$\begin{array}{l}\text { Weld root } \\
\text { (WR) }\end{array}$} & Ferrite & $\begin{array}{l}19.83 \\
(0.17)\end{array}$ & $\begin{array}{c}0.36 \\
(<0.1)\end{array}$ & $\begin{array}{c}1.35 \\
(<0.1)\end{array}$ & $\begin{array}{c}4.29 \\
(0.15)\end{array}$ & 21.01 & $\begin{array}{l}19.15 \\
(0.24)\end{array}$ & $\begin{array}{c}0.29 \\
(<0.1)\end{array}$ & $\begin{array}{c}1.36 \\
(<0.1)\end{array}$ & $\begin{array}{c}4.22 \\
(0.13)\end{array}$ & 20.11 \\
\hline & Austenite & $\begin{array}{l}19.25 \\
(0.38)\end{array}$ & $\begin{array}{c}0.18 \\
(<0.1)\end{array}$ & $\begin{array}{c}1.44 \\
(0.12)\end{array}$ & $\begin{array}{c}4.37 \\
(0.12)\end{array}$ & 19.85 & $\begin{array}{l}18.76 \\
(0.17)\end{array}$ & $\begin{array}{c}0.14 \\
(<0.1)\end{array}$ & $\begin{array}{c}1.51 \\
(0.12)\end{array}$ & $\begin{array}{c}4.46 \\
(0.17)\end{array}$ & 19.22 \\
\hline \multirow{2}{*}{$\begin{array}{c}\text { HAZ of } \\
\text { face }\end{array}$} & Ferrite & $\begin{array}{c}19.67 \\
(0.3)\end{array}$ & $\begin{array}{c}0.29 \\
(<0.1)\end{array}$ & $\begin{array}{c}1.52 \\
(0.17)\end{array}$ & $\begin{array}{c}4.22 \\
(0.29)\end{array}$ & 20.63 & $\begin{array}{l}19.59 \\
(0.18)\end{array}$ & $\begin{array}{c}0.24 \\
(<0.1)\end{array}$ & $\begin{array}{c}1.44 \\
(0.24)\end{array}$ & $\begin{array}{c}4.85 \\
(0.15)\end{array}$ & 20.38 \\
\hline & Austenite & $\begin{array}{l}18.73 \\
(0.23)\end{array}$ & $\begin{array}{c}0.27 \\
(0.11)\end{array}$ & $\begin{array}{c}1.72 \\
(0.14)\end{array}$ & $\begin{array}{c}4.6 \\
(0.2)\end{array}$ & 19.62 & $\begin{array}{l}18.49 \\
(0.29)\end{array}$ & $\begin{array}{c}0.27 \\
(0.12)\end{array}$ & $\begin{array}{c}1.93 \\
(0.18)\end{array}$ & $\begin{array}{c}5.05 \\
(0.17)\end{array}$ & 19.38 \\
\hline \multirow{2}{*}{$\begin{array}{c}\text { HAZ of } \\
\text { root }\end{array}$} & Ferrite & $\begin{array}{l}19.34 \\
(0.28)\end{array}$ & $\begin{array}{c}0.23 \\
(<0.1)\end{array}$ & $\begin{array}{c}1.41 \\
(<0.10)\end{array}$ & $\begin{array}{c}4.21 \\
(0.14)\end{array}$ & 20.10 & $\begin{array}{l}19.37 \\
(0.22)\end{array}$ & $\begin{array}{c}0.25 \\
(<0.1)\end{array}$ & $\begin{array}{c}1.28 \\
(<0.1)\end{array}$ & $\begin{array}{c}4.32 \\
(<0.1)\end{array}$ & 20.20 \\
\hline & Austenite & $\begin{array}{l}18.39 \\
(0.29)\end{array}$ & $\begin{array}{c}0.19 \\
(<0.1)\end{array}$ & $\begin{array}{c}1.61 \\
(0.17)\end{array}$ & $\begin{array}{c}4.57 \\
(0.15)\end{array}$ & 19.02 & $\begin{array}{l}18.34 \\
(0.16)\end{array}$ & $\begin{array}{c}0.20 \\
(<0.1)\end{array}$ & $\begin{array}{c}1.66 \\
(0.14)\end{array}$ & $\begin{array}{c}4.65 \\
(<0.1)\end{array}$ & 19.00 \\
\hline
\end{tabular}

PREN $=\% \mathrm{Cr}+3.3 \% \mathrm{Mo}$.

$\mathrm{SD}=$ Standard deviation.

Table 4. Quantitative determination of the degree of sensitization.

\begin{tabular}{|c|c|c|c|}
\hline \multirow{2}{*}{ WPS } & \multirow{2}{*}{ Weld region } & Electrolyte 1 & Electrolyte 2 \\
\hline & & DOS (\%) & $\mathrm{Qa}\left(\mathrm{j} / \mathrm{mA} \mathrm{cm} \mathrm{cm}^{-2}\right)$ \\
\hline \multirow{3}{*}{1} & Face & 0.22 & 11.3 \\
\hline & Fusion line & 22.39 & 54.3 \\
\hline & Root & 0.11 & 15.0 \\
\hline \multirow{3}{*}{2} & Face & 2.57 & 45.2 \\
\hline & Fusion line & 10.71 & 68.5 \\
\hline & Root & 25.59 & 61.1 \\
\hline \multicolumn{4}{|c|}{ Electrolyte 1: $0.5 \mathrm{~mol} \mathrm{~L}^{-1} \mathrm{H}_{2} \mathrm{SO}_{4}+0.01 \mathrm{~mol} \mathrm{~L}^{-1} \mathrm{KSCN}$} \\
\hline \multicolumn{4}{|c|}{ Electrolyte 2: $2.0 \mathrm{~mol} \mathrm{~L}^{-1} \mathrm{H}_{2} \mathrm{SO}_{4}+0.5 \mathrm{~mol} \mathrm{~L}^{-1} \mathrm{HCl}$} \\
\hline
\end{tabular}


Table 5. Quantitative determination of PREN and pitting potential for each WPS regions.

\begin{tabular}{|c|c|c|c|c|}
\hline \multirow{2}{*}{$\begin{array}{c}\text { Welding } \\
\text { procedure (WPS) }\end{array}$} & \multirow{2}{*}{ Weld region } & \multicolumn{2}{|c|}{ PREN } & \multirow{2}{*}{ E $_{\text {pit }}{ }^{*}(\mathbf{m V})$} \\
\cline { 3 - 5 } & & $\boldsymbol{\alpha}$ & $\boldsymbol{\gamma}$ & \\
\hline \multirow{2}{*}{1} & Face & 33.77 & 30.42 & \multirow{2}{*}{ Did not occur } \\
\cline { 2 - 5 } & Fusion line & 20.10 & 19.02 & +301 \\
\cline { 2 - 5 } & Root & 21.01 & 19.85 & Did not occur \\
\hline \multirow{2}{*}{2} & Face & 33.08 & 31.59 & +652 \\
\cline { 2 - 5 } & Fusion line & 20.20 & 19.00 & +250 \\
\cline { 2 - 5 } & Root & 20.11 & 19.22 & +555 \\
\hline
\end{tabular}

* Electrolyte: $3.5 \% \mathrm{NaCl}$ at room temperature.

Table 1. Chemical compositions (wt.\%) of UNS S32101 and ER2209.

Table 2. TIG welding conditions to the (a) WPS 1, and (b) WPS 2.

Table 3. Variance in chemical composition of austenite/ferrite for the investigated microregions.

Table 4. Quantitative determination of the degree of sensitization.

Table 5. Quantitative determination of PREN and pitting potential for each WPS regions. 